\title{
Thyroid Hormone Regulates reelin and dab1 Expression During Brain Development
}

\author{
Manuel Alvarez-Dolado, ${ }^{1,2}$ Mónica Ruiz, ${ }^{2}$ José A. Del Río, ${ }^{2}$ Soledad Alcántara, ${ }^{2}$, Ferran Burgaya, ${ }^{2}$ \\ Michael Sheldon, ${ }^{3}$ Kazunori Nakajima,, Juan Bernal, ${ }^{1}$ Brian W. Howell, ${ }^{5}$ Tom Curran, ${ }^{3}$ Eduardo Soriano, ${ }^{2}$ and \\ Alberto Muñoz ${ }^{1}$

\begin{abstract}
1/nstituto de Investigaciones Biomédicas "Alberto Sols", Consejo Superior de Investigaciones Científicas, Universidad Autónoma de Madrid, 28029 Madrid, Spain, 2Department of Animal and Plant Cell Biology, University of Barcelona, Barcelona 08028, Spain, 32Department of Developmental Neurobiology, St. Jude Research Children's Hospital, Memphis, Tennessee 38105, ${ }^{4}$ Department of Molecular Neurobiology, Institute of DNA Medicine, Jikei University School of Medicine, Minato-ku, Tokyo 105-8461, Japan, and 5Fred Hutchinson Cancer Research Center, Seattle, Washington 98109
\end{abstract}

The reelin and dab1 genes are necessary for appropriate neuronal migration and lamination during brain development. Since these processes are controlled by thyroid hormone, we studied the effect of thyroid hormone deprivation and administration on the expression of reelin and dab1. As shown by Northern analysis, in situ hybridization, and immunohistochemistry studies, hypothyroid rats expressed decreased levels of reelin RNA and protein during the perinatal period [embryonic day 18 (E18) and postnatal day 0 (P0)]. The effect was evident in CajalRetzius cells of cortex layer I, as well as in layers V/VI, hippocampus, and granular neurons of the cerebellum. At later ages, however, Reelin was more abundant in the cortex, hippocampus, cerebellum, and olfactory bulb of hypothyroid rats (P5), and no differences were detected at P15. Conversely,
Dab1 levels were higher at P0, and lower at P5 in hypothyroid animals.

In line with these results, reelin RNA and protein levels were higher in cultured hippocampal slices from PO control rats compared to those from hypothyroid animals. Significantly, thyroid-dependent regulation of reelin and dab1 was confirmed in vivo and in vitro by hormone treatment of hypothyroid rats and organotypic cultures, respectively. In both cases, thyroid hormone led to an increase in reelin expression. Our data suggest that the effects of thyroid hormone on neuronal migration may be in part mediated through the control of reelin and dab1 expression during brain ontogenesis.

Key words: reelin, dab1, thyroid hormone, neuronal migration, cortical lamination, brain development
Neuronal migration is an essential step in the genesis of the nervous system, particularly in laminated brain regions (MarínPadilla, 1971, 1998; Rakic, 1988, 1990; Hatten, 1993). Abnormal migration of neurons has been linked to cognitive deficits, mental retardation, and motor disorders (Eksloglu et al., 1996; Sheldon et al., 1997; Howell et al., 1997b; des Portes et al., 1998; Gleeson et al., 1998).

The study of mouse mutants has led to identify some of the molecules that regulate neuronal positioning. The reeler mutant has severe abnormalities in the neocortex, hippocampus, and cerebellum (Caviness and Sidman, 1973; Mariani et al., 1977; Goffinet, 1980, 1992; Derer, 1985; Rakic and Caviness, 1995). Characterization of the defective gene in these mice showed that it encoded a large extracellular protein, Reelin, that is expressed in discrete regions of the developing brain (D'Arcangelo et al., 1995, 1997; Hirotsune et al., 1995; Ogawa et al., 1995). reelin is

Received March 15, 1999; revised May 11, 1999; accepted May 21, 1999.

This work was supported by grants from Comisión Interministerial de Ciencia y Tecnología, Plan Nacional de Salud (SAF98-0060 to A.M. and SAF98-0106 to E.S.), by Marató de TV3 Foundation to E.S., by the National Cancer Institute (Grant CA41702) to Jonathan Cooper and B.H., and by the Japanese Ministry of Education, Science, and Culture to K.N. T.C. was supported in part by National Institutes of Health Cancer Center Support CORE Grant P30 CA21765 and by the American Lebanese Syrian Associated Charities. E.S., K.N., and T.C. were supported also by the Human Frontier Science Program Organization. We thank Fernando Núñez and Pablo Señor for the care of animals, and Margarita González for technical help.

Correspondence should be addressed to Dr. Alberto Muñoz, Instituto de Investigaciones Biomédicas, Arturo Duperier, 4, 28029 Madrid, Spain.

Copyright (C) 1999 Society for Neuroscience 0270-6474/99/196979-15\$05.00/0 expressed by different sets of neurons, including the pioneer Cajal-Retzius (CR) cells in layer I of the cerebral cortex and the granule cells of the cerebellum (D'Arcangelo et al., 1995; Ogawa et al., 1995; Miyata et al., 1996; Nakajima et al., 1997; Schiffman et al., 1997; Alcántara et al., 1998). In addition to controlling neuronal position, Reelin influences the growth and targeting of hippocampal afferents (Del Río et al., 1997; Borrell et al., 1999). Reelin probably acts directly on migrating neurons through an uncharacterized receptor or receptors. In support of this, Reelin is found in association with neurons that do not express reelin RNA (Ogawa et al., 1995; Miyata et al., 1996). Although the mediator of Reelin function is unknown, it seems likely that mouse dabl gene product acts on the same signaling cascade. Loss of function alleles of $d a b 1$ produce a mutant phenotype that closely resembles the reeler mutant (Sheldon et al., 1997; Howell et al., 1997b; Rice et al., 1998). Also, Dab1 is upregulated in reeler mice (Rice et al., 1998). Since Reelin regulates Dab1 phosphorylation, Dab1 may act within migrating neurons in response to a Reelin signal (Howell et al., 1999). Little is known about the physiological factors that regulate Reelin expression. Only recently, brain-derived neurotrophic factor (BDNF) has been described to downregulate reelin expression (Ringstedt et al., 1998).

Thyroid hormone [3,5,3'-triiodothyronine (T3) and thyroxine (T4)] deficiency during the perinatal period leads to cretinism, a syndrome associated with mental retardation and neurological deficits (for review, see DeLong, 1990; Porterfield and Hendrich, 1993). In experimental animals, thyroid hormone deficiency 
causes an array of abnormalities in the CNS of which alterations of cell migrations are of special relevance. In rodents, there is a delayed migration of cerebellar granule neurons, positional alterations of Purkinje cells, and abnormalities in cerebral cortex lamination with ectopic location of neurons (Patel et al., 1976; Legrand, 1984; Berbel et al., 1993; Lucio et al., 1997).

A number of brain genes have been identified as regulated by thyroid hormone. They include those coding for the major myelin proteins, cytoskeletal proteins, neurotrophins and their receptors, transcription factors, and intracellular signaling proteins (for review, see Oppenheimer and Schwartz, 1997; Bernal and Guadaño-Ferraz, 1998). None of these target genes are directly involved in neuronal migration. Therefore, we investigated whether the expression of two genes critical for neuronal migration, reelin and dab1, is regulated by thyroid hormone. We show that reelin expression is severely decreased in hypothyroid rats at the perinatal stage, but dabl mRNA expression is not altered. Interestingly, Dab1 accumulates whereas the level of Reelin is reduced. Significantly, hormone treatment restores the normal pattern of reelin expression in vivo and in vitro, indicating that the hormone is involved in the regulation of the reelin gene.

\section{MATERIALS AND METHODS}

Animals. Wistar rats maintained in the animal facilities of our Instituto de Investigaciones Biomédicas were used for the studies reported here. All efforts were made to minimize animal suffering, to reduce the number of animals used, and to use alternatives to in vivo techniques. The maintenance and handling of the animals were as recommended by the European Communities Council Directive of November 24th, 1986 (86/609/EEC). To induce fetal and neonatal hypothyroidism (E18, P0, P5) 2-mercapto-1-methylimidazole (MMI; 0.02\%, Sigma, St. Louis, MO) was administered in the drinking water of the dams from the ninth day after conception and was continued until the animals were killed. MMI blocks both maternal and fetal thyroid hormone synthesis by inhibiting thyroglobulin iodination (Yamada et al., 1974; Marchant et al., 1977). In addition, surgical thyroidectomy was performed at P5, as previously described (Rodríguez-Peña et al., 1993; Alvarez-Dolado et al., 1994). This protocol ensures that the animals are hypothyroid during the entire neonatal period (Muñoz et al., 1991; Alvarez-Dolado et al., 1998). P0 animals were killed 8-12 hr after birth. T4 was used for the in vivo hormonal treatments because it crosses the blood-brain barrier more efficiently than T3, and is converted to T3 in the brain (Dickson et al., 1987). T4 was administered as single daily intraperitoneal injections of $1.8 \mu \mathrm{g} / 100 \mathrm{gm}$ body weight starting $4 \mathrm{~d}$ before death. Rats were killed 24 hr after the last T4 injection. At least three animals were studied per experimental group to obtain representative values.

RNA extraction and Northern analysis. To prepare total RNA we used the guanidinium isothiocyanate-phenol-chloroform procedure (Chomczynsky and Sacchi, 1987). Poly(A) ${ }^{+}$RNA was purified by affinity chromatography using oligo-dT-cellulose (Vennström and Bishop, 1982). RNAs were fractionated in formaldehyde agarose gels and blotted onto nylon membranes following standard techniques (Sambrook et al., 1989). As controls for the amount and integrity of RNA present in the filters, blots were stained in a $0.02 \%$ methylene blue solution made in $0.3 \mathrm{M}$ sodium acetate and rehybridized with a cyclophilin $(\mathrm{Cy})$ cDNA probe (Muñoz et al., 1991). Radioactive probes were prepared by the random priming procedure (Feinberg and Vogelstein, 1983). Ten micrograms of poly (A) ${ }^{+}$ RNA from different brain regions was loaded per lane. The reelin probe was a 1540 bp fragment (positions 1532 to 3071) from the mouse cDNA (D'Arcangelo et al., 1995). The Cy probe was from Dr. J. G. Sutcliffe (Scripps Research Institute, San Diego, CA).

In situ hybridization and immunocytochemistry. In situ hybridization was performed on free-floating sections essentially as described (de Lecea et al., 1994, 1997; Alcántara et al., 1998). Tissue preparation and hybridization of control and hypothyroid rats were performed in bulk. Animals at embryonic day 18 (E18) and postnatal day 0 (P0), P5, and P15 were perfused with $4 \%$ paraformaldehyde. After fixation and infiltration with sucrose, brains were frozen in dry ice. Coronal and horizontal sections (thickness: $50 \mu \mathrm{m}, \mathrm{E} 18 ; 30 \mu \mathrm{m}, \mathrm{P} 0-\mathrm{P} 5 ; 25 \mu \mathrm{m}, \mathrm{P} 15$-adult) were collected in a cryoprotectant solution (30\% glycerol, $30 \%$ ethylenglycol,
$40 \% 0.1 \mathrm{M}$ PBS, and stored at $-60^{\circ} \mathrm{C}$ until use. Sections were permeabilized in $0.2-0.5 \%$ Triton $\mathrm{X}-100(15 \mathrm{~min})$, treated with $2 \% \mathrm{H}_{2} \mathrm{O}_{2}(15 \mathrm{~min})$, deproteinized with $0.2 \mathrm{~N} \mathrm{HCl}(10 \mathrm{~min})$, fixed in $4 \%$ paraformaldehyde $(10 \mathrm{~min})$, and blocked in $0.2 \%$ glycine $(5 \mathrm{~min})$. Thereafter, sections were prehybridized at $60^{\circ} \mathrm{C}$ for $3 \mathrm{hr}$ in a solution containing $50 \%$ formamide, $10 \%$ dextran sulfate, $5 \times$ Denhardt's solution, $0.62 \mathrm{M} \mathrm{NaCl}, 10 \mathrm{~mm}$ EDTA, 20 mM PIPES, pH 6.8, 50 mM DTT, $250 \mu \mathrm{g} / \mathrm{ml}$ yeast tRNA, and $250 \mu \mathrm{g} / \mathrm{ml}$ denatured salmon sperm DNA. Riboprobes were labeled with digoxigenin-dUTP (Boehringer Mannheim, Indianapolis, IN) by in vitro transcription of a cDNA fragment encoding mouse reelin (D'Arcangelo et al., 1995) or mouse dab1 (Rice et al., 1998) using T3 polymerase. Labeled antisense cRNA was added to the prehybridization solution (500 $\mathrm{ng} / \mathrm{ml}$ ) and hybridization was carried out at $60^{\circ} \mathrm{C}$ overnight. Sections were then washed in $2 \times \mathrm{SSC}$ (30 min, room temperature), digested with $20 \mu \mathrm{g} / \mathrm{ml}$ RNase A $\left(37^{\circ} \mathrm{C}, 1 \mathrm{hr}\right)$, washed in $0.5 \times \mathrm{SSC} / 50 \%$ formamide $(4$ $\left.\mathrm{hr}, 55^{\circ} \mathrm{C}\right)$ and in $0.1 \times \mathrm{SSC} / 0.1 \%$ sarkosyl $\left(1 \mathrm{hr}, 60^{\circ} \mathrm{C}\right)$. Sections were blocked in $10 \%$ normal goat serum ( $2 \mathrm{hr}$ ) and incubated overnight with an alkaline phosphatase-conjugated antibody to digoxigenin (Boehringer Mannheim, 1:2000). After washing, sections were developed with nitroblue tetrazolium and 5-bromo-4-chloro-3-indolyl phosphate (Life Technologies, Gaithersburg, MD), mounted on gelatin-coated slides and coverslipped with Mowiol.

For immunocytochemistry, embryos and postnatal rats were perfused with $2 \%$ paraformaldehyde and sectioned as above. Sections were incubated with the CR50 monoclonal antibody (dilution 1:2000) that recognizes the N-terminal region of Reelin (Ogawa et al., 1995; D'Arcangelo et al., 1997). The primary antibody was visualized using a biotinylated secondary antibody (1:200) and a streptavidin-peroxidase complex (1: 400) (Vector Laboratories, Burlingame, CA). Peroxidase reactions were developed using diaminobenzidine and $\mathrm{H}_{2} \mathrm{O}_{2}$. For detecting of Dab1 we used a rabbit polyclonal antibody (B3; dilution 1:2000) previously described (Howell et al., 1997a).

Organotypic slice cultures. Hippocampal slice cultures were prepared from normal $(n=10)$ and hypothyroid rats $(n=10)$ essentially as described (Del Río et al., 1996, 1997). P0 animals were anesthetized by hypothermia, and the hippocampus and the prospective parietal cortex were dissected out. Transverse slices (300- to 350-mm-thick) were obtained by cutting tissue pieces in a McIlwain tissue chopper (Mickle Laboratory Engineering, Gomshall, UK). Selected slices were maintained in Minimum Essential Medium (MEM) supplemented with L-glutamine $(2 \mathrm{mM})$ for $45 \mathrm{~min}$ at $4^{\circ} \mathrm{C}$. Thereafter, slices were cultured using the membrane interphase technique (Stoppini et al., 1991). Incubation medium was $50 \%$ MEM, $25 \%$ horse serum, $25 \%$ HBSS, supplemented with L-glutamine $(2 \mathrm{mM})$. Experimental groups comprised cultures established from hypothyroid pups incubated in normal serum $(n=$ $24)$ or in T3/T4-depleted serum $(n=24)$ with or without daily added T3 (150 nM, $n=24$, or $500 \mathrm{nM}, n=24)$. Organotypic cultures from newborn control rats were distributed in similar groups: normal serum $(n=24)$, T3/T4-depleted serum alone $(n=24)$, or supplemented daily with T3 $(150 \mathrm{nM} n=24$, or $500 \mathrm{nM}, n=24)$. After 6 days in vitro (DIV) cultures were fixed with $4 \%$ paraformaldehyde in $0.1 \mathrm{M}$ phosphate buffer and stored. After several rinses, $50-\mu \mathrm{m}$-thick sections were obtained using a vibratome, and processed for the detection of reelin mRNA and protein by in situ hybridization and immunocytochemistry as described above.

For quantitative RT-PCR analysis, total RNA from six organotypic slices was extracted by nondenaturing methods (Sambrook et al., 1989) and resuspended in $20 \mu \mathrm{l}$ of distilled water. Four microliter aliquots were retrotranscribed and amplified by using Retrotools cDNA/DNA polymerase kit (Biotools, Madrid, Spain) according to the manufacturer's instructions (labeling was performed at $\mathrm{Tm}-3^{\circ} \mathrm{C}$, and amplification was run up to 25 cycles, with Taq polymerase). For reelin assays, the forward primer was ATACGTGGATCCCTGTATCTACTTGCTGTGTTGC, and the reverse primer was ATACGTCTAGACAAGTCACTTTGTTACCACAG, corresponding to the 342 bp terminal sequence of the mouse reelin $3^{\prime}$ untranslated region (D'Arcangelo et al., 1995). For glyceraldehyde phosphate dehydrogenase (GAPDH) assays, the forward primer was GGCCCCTCTGGAAAGCTGTGG, and the reverse primer was CCTTGGAGGCCATGTAGGCCAT, covering a 435 bp coding sequence between nucleotides 608 and 1043 of mouse GAPDH cDNA (Sabath et al., 1990). PCR products were run in $1.2 \%$ agarose gels, transferred to nylon membranes, and hybridized to ${ }^{32} \mathrm{P}$-labeled forward primer by standard procedures (Sambrook et al., 1989). Results were analyzed in an Instant Imager apparatus (Packard, Meridian, CT), and data were expressed as counts per minute.

Brain extract preparation and immunoblot analysis. Protein extracts 


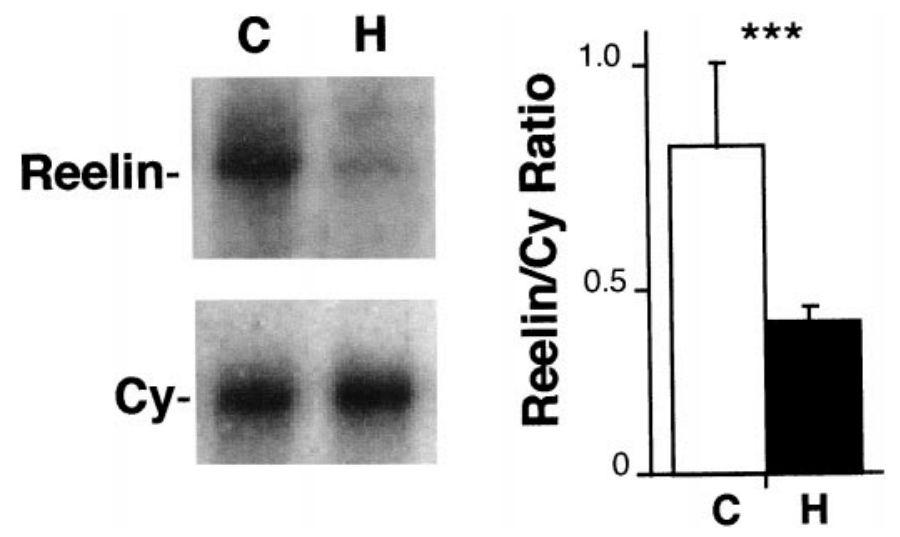

Figure 1. Northern analysis of reelin RNA expression in newborn hypothyroid rats. Ten micrograms of $\operatorname{poly}(A)^{+}$RNA from cerebral cortex of control $(C)$ and hypothyroid $(H)$ newborn $(\mathrm{P} 0)$ rats (each sample corresponded to three pooled animals) were analyzed in Northern blots using a reelin cDNA probe as described in Materials and Methods. Cyclophilin (Cy) was used as a control gene. The levels of reelin RNA were quantitated using an Instant Imager apparatus (Packard). Data from three independent experiments are shown as mean \pm SEM; ${ }^{* * *} p<0.001$.

from the cerebral cortex and cerebellum of P0 and P5 control and hypothyroid rats, and total brains from E17 or newborn wild-type and reeler mutant mice were prepared by dounce homogenizing the tissue that was snap-frozen in liquid nitrogen in $500 \mu \mathrm{l}$ of ice-cold lysis buffer (0.1\% NP-40, 250 mм NaCl, 50 mm Tris-HCl, pH 7.4, 1 mm EDTA, 2 mM PMSF, $20 \mu \mathrm{M}$ leupeptin, and $50 \mathrm{~mm} \mathrm{NaF}$ ) per $100 \mathrm{mg}$ tissue. Extracts were cleared by centrifugation at $14,000 \mathrm{rpm}$ for $30 \mathrm{~min}$. One hundred micrograms of protein extract was loaded per lane onto a $4-12 \%$ polyacrylamide gradient gel (Novagen, Madison,WI), electrotransfered to nitrocellulose membranes, incubated with a rabbit polyclonal antibody directed against the phosphotyrosine binding (PTB) domain of mDab1 (antibody PTB31) and visualized by enhanced chemiluminescence (Boehringer Mannheim). Blots were stripped and reprobed with an anti-ref-1 antibody (Xanthoudakis et al., 1992) as an internal control for equal amounts of protein loading.

Controls. Control hybridizations with sense digoxigenin-labeled riboprobes, or RNase A digestion before hybridization, prevented alkaline phosphatase staining above background levels. In immunocytochemical controls, omission of the primary antibody prevented diaminobenzidine staining. For RT-PCR assays, RNA samples were digested with DNase I by standard procedures (Sambrook et al., 1989) and then subjected to direct PCR analysis.

Data analysis. Sections were examined on a Reichert Polyvar microscope. The delimitation of regional and laminar boundaries was performed according to Sidman et al. (1971), Zilles (1985), and Paxinos et al. (1994). The number of labeled neurons present in neocortical layer I (prospective parietal cortex) and in the stratum lacunosum-moleculare of hippocampus was determined in horizontal strips (400 $\mu \mathrm{m}$ length) covering the entire thickness of these layers (Del Río et al., 1995). For the quantifications in layers V-VI, the number of labeled cells present in $9 \times$ $10^{4} \mu \mathrm{m}^{2}$ was counted. For each group and age, counts were performed in four to six sections per animal (two to five animals per group). Data (expressed as means of cell counts \pm SEM) were compared by ANOVA and post hoc $t$ tests.

\section{RESULTS}

\section{reelin mRNA expression is downregulated in the cerebral cortex of hypothyroid rats}

To determine whether reelin expression was altered by thyroid hormone depletion in the developing rat brain, we first analyzed reelin mRNA levels by Northern blot hybridization. As shown in Figure 1, reelin RNA expression was markedly downregulated in the cerebral cortex of hypothyroid rats at P0 (50-60\% decrease). Recent studies have shown that reelin is differentially expressed in several regions of the developing brain (Schiffman et al., 1997;
Alcántara et al., 1998; Rice et al., 1998). To gain insight into the regional differences in the regulation of reelin expression by thyroid hormone, we performed in situ hybridization analyses. We first focused on the pattern of developmental expression in the neocortex and hippocampus, two regions that are targets of thyroid hormone action. At E18-P0 reelin transcripts were very prominent in neurons present in the marginal zone of the neocortical and hippocampal anlage [prospective layer I and stratum lacunosum-moleculare (SLM), respectively] (Figs. 2A,G, 3) These neurons were intensely labeled and displayed large, horizontally-oriented perikarya, which are typical for CR cells (Soriano et al., 1994; Del Río et al., 1995, 1997; Alcántara et al., 1998). In agreement with earlier studies (Schiffman et al., 1997; Alcántara et al., 1998), reelin-positive CR cells were more numerous in the hippocampus than in the neocortex (data not shown). The pattern of reelin expression at E18 and P0 was similar in layer I/SLM. A second population of reelin-positive neurons was detected at $\mathrm{P} 0$ in layers V/VI of the neocortex (Fig. $2 A$ ) and in the plexiform layers of the hippocampus (Schiffman et al., 1997; Alcántara et al., 1998).

In hypothyroid rats, the regional and laminar patterns of reelin expression at E18-P0 were similar to those in control rats. However, the number of labeled neurons in layer I of the neocortex and in the SLM of the hippocampus was significantly lower, particularly at P0 (Figs. 2B, 3). Moreover, reelin-positive CR neurons clearly displayed weaker hybridization signals in hypothyroid rats than in controls (Fig. $2 H$ ). Both the number of positive neurons and their intensity of labeling were lower in layers V/VI of the neocortex and in the hippocampal plexiform layers at $\mathrm{P} 0$ (Figs. 2B, 3).

At P5 the levels of reelin RNA expression were slightly lower in layer I/SLM than at previous stages, although a substantial number of positive neurons was still present, particularly in the hippocampus (Fig. 2C,I). No significant differences were found in these layers in the number of positive neurons between control and hypothyroid rats (Fig. 3), although neurons displayed weaker signals in hypothyroid rats (Fig. 2, compare $I, J$ ). In contrast, the number of reelin-positive neurons in layers II-VI was decreased in hypothyroid rats (Fig. 3).

At $\mathrm{P} 15$, reelin transcripts were detected in a few neurons in layer I of the neocortex and in neurons scattered within layers II-VI (Fig. 2E), which are known to correspond to certain GABAergic neurons (Alcántara et al., 1998). In the hippocampus, reelin $R N A$ expression was still detected in CR cells as well as in some interneurons distributed within the plexiform layers (Fig. $2 K$ ). The pattern of expression in hypothyroid rats was similar to that in controls (Figs. $2 F, 3$ ). These data demonstrate that reelin RNA expression is downregulated by hypothyroidism at late prenatal and early postnatal stages of corticogenesis.

\section{Distribution of Reelin immunoreactivity in the cerebral cortex of hypothyroid rats}

To investigate whether Reelin distribution was also altered in hypothyroid rats, brain sections were immunostained with the CR50 mAb that recognizes the N-terminal region of Reelin (Ogawa et al., 1995; D’Arcangelo et al., 1997). At E18-P0, CR50 immunoreactivity was very prominent in layer I/SLM of control rats, labeling the perikarya and dendrites of CR cells (Fig. 4A,E). In addition, there was diffuse staining in layer I/SLM, which is likely to correspond to the distribution of extracellular Reelin. In the cerebral cortex of hypothyroid rats, CR50 immunostaining was much weaker in layer I/SLM, particularly at P0 (Fig. 4B,F). 


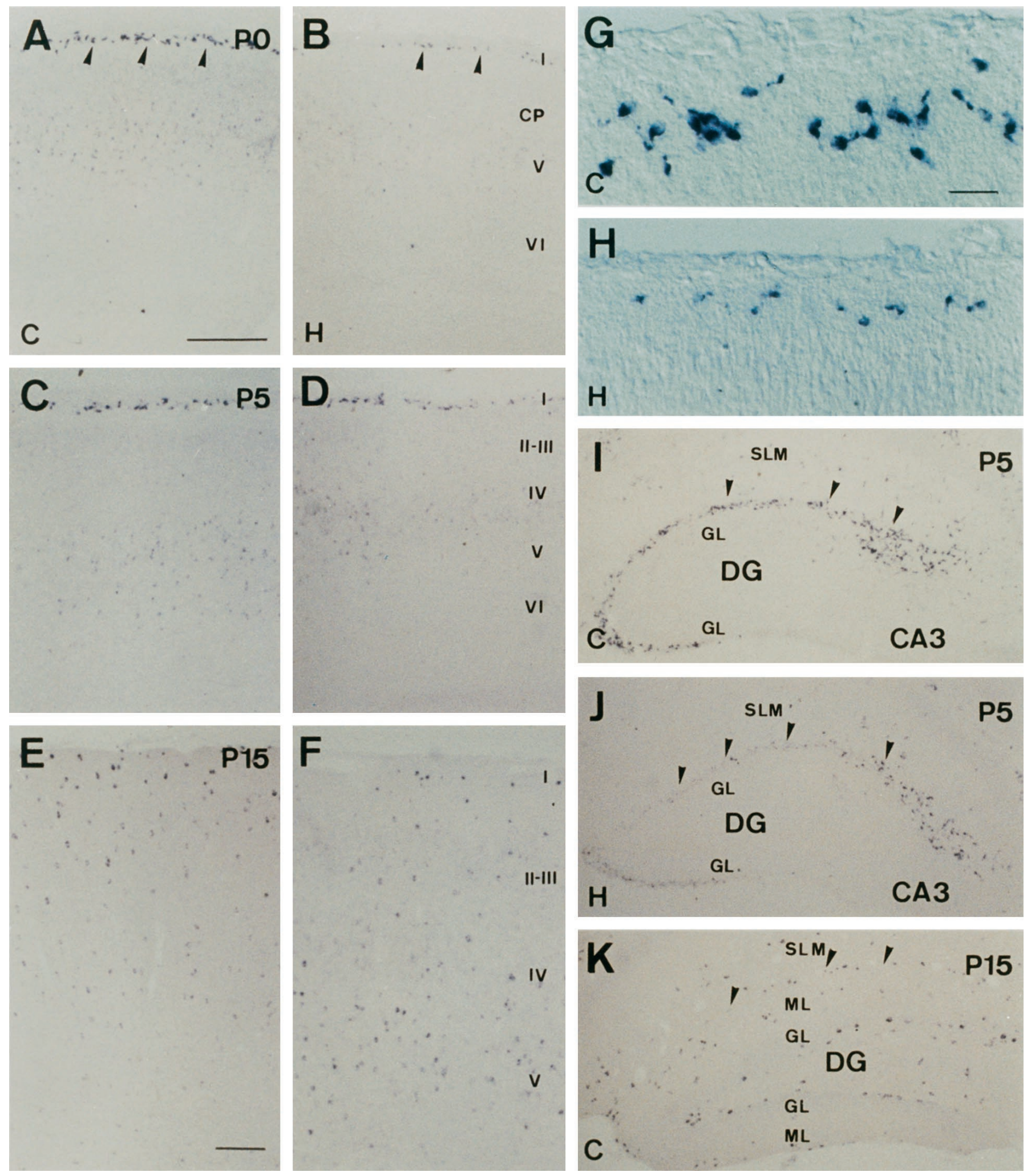

Figure 2. Effects of hypothyroidism on reelin RNA expression in the cerebral cortex. $A-F$, Pattern of reelin RNA expression in the neocortex of control $(A, C, E)$ and hypothyroid $(B, D, F)$ rats at $\mathrm{P} 0(A, B), \mathrm{P} 5(C, D)$, and $\mathrm{P} 15(E, F)$. Cortical layers are indicated to the right. Note the decreased RNA levels in hypothyroid rats at $\mathrm{P} 0$ and P5. Arrowheads in $A$ and $B$ point to CR cells. $G, H$, High magnification photomicrographs illustrating reelin RNA-positive CR cells in layer I of the neocortex in control $(G)$ and hypothyroid rats $(H)$. I, J, Distribution of reelin RNA-positive cells in the hippocampus of control $(I)$ and hypothyroid $(J)$ rats at P5, showing decreased RNA levels both in the stratum lacunosum-moleculare and in the remaining hippocampal layers. $K$, Distribution of reelin RNA-positive cells in the hippocampus of a control rat at P15. No differences were detected in hypothyroid rats at this age in this region. $C$, Control; $H$, hypothyroid; $I-V I$, cortical layers; $C P$, cortical plate; $D G$, dentate gyrus; $G L$, granule cell layer; $M L$, molecular layer; $C A 3$, $C A 1$, hippocampal subdivisions CA3 and CA1; SLM, stratum lacunosum-moleculare. Scale bars: $A, 200 \mu \mathrm{m}$ (applies to $B-D, I, J) ; E, 100 \mu \mathrm{m}$ (applies to $\mathrm{F}, \mathrm{K}) ; \mathrm{G}, 40 \mu \mathrm{m}$ (applies to $H$ ). 

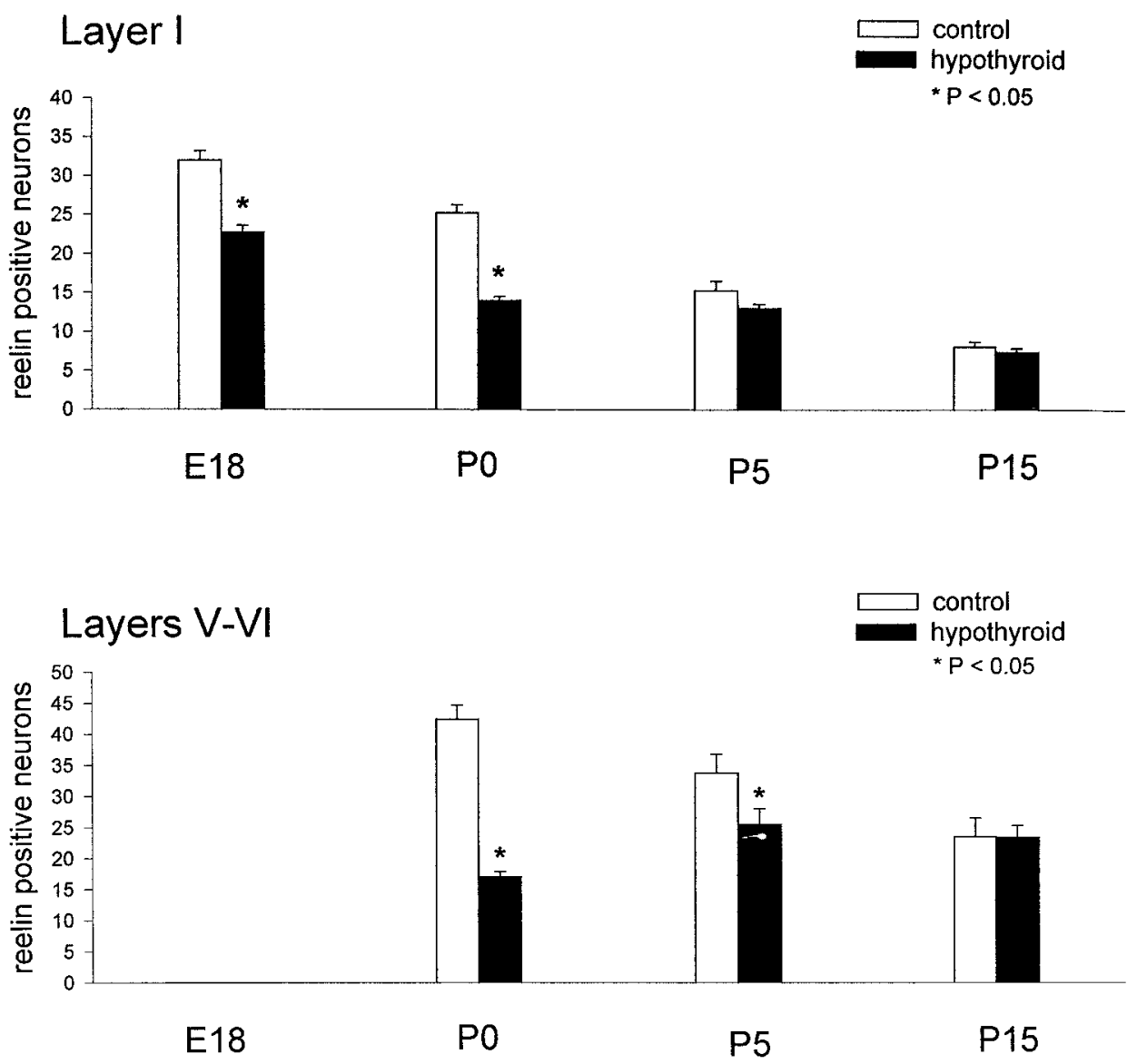

\section{Hippocampus (slm)}

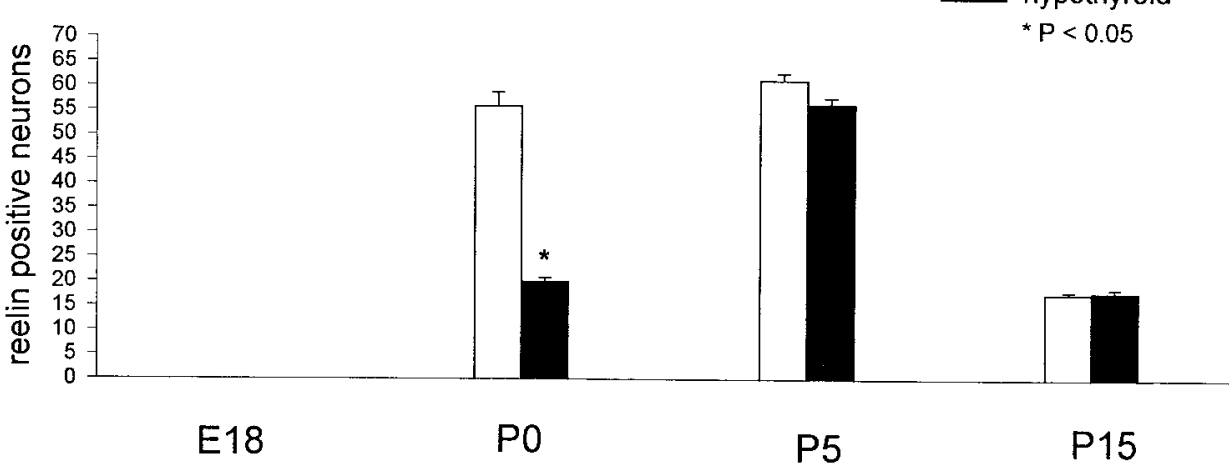

Figure 3. Number of reelin RNA-positive neurons in control and hypothyroid rats in layer I and layers V/VI of the neocortex and in the stratum lacunosum-moleculare of the hippocampus. Data were quantitated as described in Materials and Methods (mean \pm SEM; ${ }^{*} p<0.05$ ). For cortical layer I and stratum lacunosum-moleculare, we analyzed four strips of three different animals, and for layers V/VI, we measured five sections of three different animals.
Immunoreactive neurons were difficult to identify in layer I/SLM of newborn hypothyroid rats, and the diffuse staining observed in control rats was drastically reduced (Fig. 4B,F). Furthermore, a few Reelin-positive neurons were observed in layers V-VI of the cortex and in the hippocampal plexiform layers in control rats, which could not be detected in hypothyroid rats (data not shown).

At P5, the pattern of Reelin immunostaining in layer I/SLM of control rats was similar to that seen at previous stages (Fig. 4C, $G$ ). In contrast to the perinatal stages, a large number of CR50positive neurons were also present in layer I/SLM of P5 hypothyroid rats, with the diff use extracellular-like staining being very prominent (Fig. 4D,H). In fact, the intensity of immunolabeling at P5 was slightly higher in hypothyroid rats than in control rats.
At P15 a few Reelin-positive neurons populated layer I/SLM and the remaining neocortical and hippocampal layers in control rats. No clear differences were apparent in the distribution of Reelin-positive neurons in hypothyroid rats (Fig. 4I-L), although cells were more weakly stained in these experimental animals. Taken together, the data show that Reelin levels are decreased at perinatal stages in hypothyroid rats, whereas they appear to reach normal levels at later postnatal stages.

\section{reelin expression in the cerebellum and olfactory bulb of hypothyroid rats}

We next examined the developmental distribution of reelin mRNA and protein in the cerebellum and olfactory bulb, two 

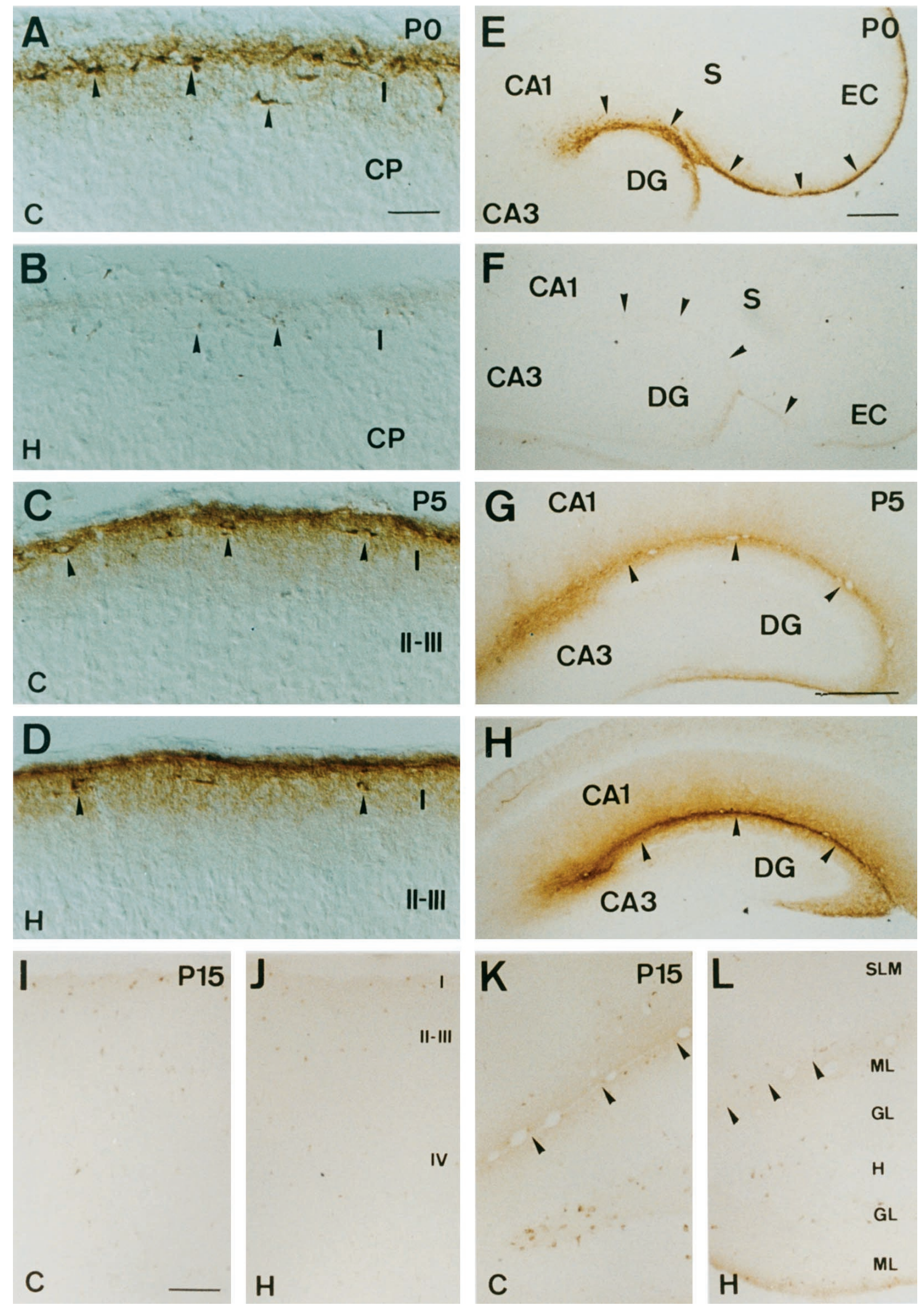

Figure 4. Reelin expression in the cerebral cortex of control and hypothyroid rats. $A-D$, Photomicrographs showing the distribution of CR50 immunostaining in layer I of control $(A, C)$ and hypothyroid rats $(B, D)$ at $\mathrm{P} 0(A, B)$ and $\mathrm{P} 5(C, D)$. Some CR50-positive CR cells are indicated by arrowheads. Note the decreased staining at P0 in hypothyroid animals. $E-H$, Pattern of CR50 immunostaining in the hippocampus of control $(E$, $G)$ and hypothyroid rats $(F, H)$ at $\mathrm{P} 0(E, F)$ and $\mathrm{P} 5(G, H)$, illustrating a clear reduction in the staining in hypothyroid rats at P0. The hippocampal fissure is indicated by arrowheads. $I-L$, Pattern of CR50 staining in the neocortex $(I, J)$ and hippocampus $(K, L)$ of control $(I, K)$ and hypothyroid $(J, L)$ rats at P15. No marked differences were found in both cortical regions at this age. $C$, Control; $\mathrm{H}$, hypothyroid; EC, entorhinal cortex; other abbreviations are as in legend to Figure 2. Scale bars: $A, 40 \mu \mathrm{m}$ (applies to $B-D$ ); $E, 200 \mu \mathrm{m}$ (applies to $F$ ); $G, 200 \mu \mathrm{m}$ (applies to $H$ ); $I, 100 \mu \mathrm{m}($ applies to $J-L$ ). 
regions of high reelin expression in which migration deficits have been reported in hypothyroid rats (Patel et al., 1976; Legrand, 1984). At E18-P0 reelin transcripts and CR50 immunoreactivity in the cerebellum were detected in the external granule cell layer (EGL) and in a population of neurons in the prospective internal granule cell layer (IGL), which may correspond to the first postmigratory granule cells (see Miyata et al., 1996). Both the hybridization and the immunocytochemical signals were lower in the cerebellum of hypothyroid rats (Fig. $5 A, B$ ). In contrast, no remarkable changes in expression levels or immunohistochemical signals were observed in the primordium of the olfactory bulb at these ages (data not shown).

At $\mathrm{P} 5-\mathrm{P} 15$ reelin $\mathrm{mRNA}$ and $\mathrm{CR} 50$ immunolabeling were prominent in both the EGL and the IGL of the cerebellum (Fig. $5 C, E, G, I)$. Although the EGL is thicker in the hypothyroid rat brain because of the delayed migration of granule cells, the distribution of reelin RNA and protein was similar in control and hypothyroid rats at P5-P15 (Fig. 5D,F,H,J). However, both mRNA and protein levels were clearly elevated in the cerebellum of hypothyroid rats at these ages. In the olfactory bulb, decreased levels of RNA and protein were noticed at P5 in hypothyroid rats (Fig. $5 K, L$ ), whereas no changes were detected at P15.

\section{Developmental regulation of dab1 mRNA and protein in hypothyroid rats}

Recent studies have shown that mutations in the dab1 gene, which encodes an adaptor protein that appears to function in signal transduction processes, leads to cytoarchitectonic alterations similar to those in reeler mutant mice (Sheldon et al., 1997; Howell et al., 1997b; Rice et al., 1998). This suggests that Dab1 acts in the same signaling pathway of Reelin that controls cell positioning in the developing brain. To determine whether dab1 expression was altered in hypothyroid rats, we performed in situ hybridization analyses. At E18 and P0 dab1 transcripts were widely distributed in the proliferative ventricular zone as well as in postmitotic neurons of the cerebral cortex. Both the cortical plate in the neocortex and the pyramidal and granule cell layers of the hippocampus were intensely labeled. In other brain regions such as the cerebellum, widespread expression was also noticed (data not shown), which is consistent with recent studies (Rice et al., 1998). No changes in the distribution of transcripts or the intensity of the hybridization signal were observed in hypothyroid rats at E18-P0 (Fig. 6A,B). At P5-P15 dab1 expression was also widespread in the neocortex and hippocampus with many labeled neurons evident (Fig. 6C,D). In the cerebellum dab1 was expressed in Purkinje cells, in the IGL, and in the inner part of the EGL (data not shown). Again, no major changes were detected in hypothyroid rats, except for a slightly lower signal at P5. These data indicate that $d a b 1$ RNA synthesis or stability is not substantially altered by the lack of thyroid hormone.

We next examined the distribution of Dab1 protein, which accumulates to abnormally high level in the absence of Reelin in reeler mice (Rice et al., 1998). At P0, Dab1 immunoreactivity was detected in the perikarya and dendrites of many postmitotic neurons of the neocortex and hippocampus, as well as in fiber tracts in control rats (Fig. 6E; data not shown). At this age, hypothyroid brains showed a similar distribution of Dab1 protein; however the intensity of immunostaining was higher compared to that in control rats (Fig. 6E,F). At P5, the distribution of Dab1 in the cerebral cortex remained widespread in both control and hypothyroid rats. However, at P5 the levels of immunostaining were higher in control than in hypothyroid rats (Fig. 6, compare
$G, H)$. The same difference in Dab1 expression was found in the cerebellum (Fig. 6I,J). At later developmental stages (P15, P25) no differences were seen between controls and hypothyroid rats (data not shown).

To further confirm these data, we analyzed the amount of Dab1 protein in cortex and cerebella from control and hypothyroid animals by Western blotting. As shown in Figure 7, at P5 Dab1 was more abundant in control rats. These results indicate that the levels of Dab1 are inversely correlated with those of Reelin in hypothyroid rats, as recently shown in the reeler mutant mouse (Rice et al., 1998). This also implies that Dab1 fails to be degraded in the absence of a Reelin-evoked signal. Brain samples from wild-type and reeler mice were included as controls, showing the upregulation of Dab1 expression in mutant animals lacking Reelin.

\section{reelin expression is regulated by thyroid hormone in vivo and in vitro}

To test whether reelin expression is directly regulated by thyroid hormone, organotypic hippocampal slices from control and hypothyroid $\mathrm{P} 0$ rats were incubated in culture medium containing either normal serum or T3/T4-depleted serum supplemented or not with T3 (150 or $500 \mathrm{~nm}$ ). After $6 \mathrm{~d}$ in culture, reelin mRNA expression was analyzed by in situ hybridization. Slices from control rats incubated in the T3/T4-depleted or normal serum showed the typical pattern of reelin mRNA-positive neurons. Thus, intensely labeled CR cells were present in the SLM near the hippocampal fissure, and a few additional scattered neurons were present in the remaining layers (Fig. 8A,D; data not shown). Control slices incubated with T3 did not exhibit a statistically significant increase in the number of reelin-positive neurons (Fig. 9). These data suggest that the effect of hormone-depleted serum in vitro may not be as severe as long-term hypothyroidism in vivo.

Slices from hypothyroid newborn rats cultured with either normal or hormone-depleted sera displayed a marked reduction in the number of reelin-positive cells after $6 \mathrm{~d}$ (Figs. 8B,E, 9). This result was in contrast to the similar number of reelin-expressing cells found in the hippocampus of control and hypothyroid rats at P5 (Fig. 3), and indicates that additional systemic factors regulating reelin expression may exist that are not present in slice cultures. Furthermore, the labeled neurons exhibited weak hybridization signals. In contrast, hypothyroid hippocampal slices treated with T3 displayed a pattern of expression indistinguishable from that of control cultures, indicating that thyroid hormone restores reelin expression to normal levels (Fig. 8C,F). This result was confirmed by counting positive cells (Fig. 9). Additionally, the effect of $\mathrm{T} 3$ on reelin RNA expression in the organotypic cultures was estimated by using a semiquantitative RT-PCR analysis. In line with the above data, T3 treatment restored reelin RNA expression in hypothyroid rats to normal levels, and led to a threefold increase in control animals (Fig. 10).

To examine whether the regulation of reelin RNA expression correlated with protein levels, hippocampal slices were immunostained with the CR50 antibody. As seen in Figure 8 (compare panels $G$ and $J$ with $H$ and $K$ ) the robust CR50 immunostaining seen in control slices was dramatically reduced in hippocampal slices from hypothyroid rats. Again, the pattern of CR50 immunostaining returned to normal when these cultures were treated with T3 for $6 \mathrm{~d}$ (Fig. 8I,L).

To determine if reduced hormone levels in hypothyroid rats was the cause of the observed decreased reelin expression, we administered T4 to these animals. In agreement with the above 

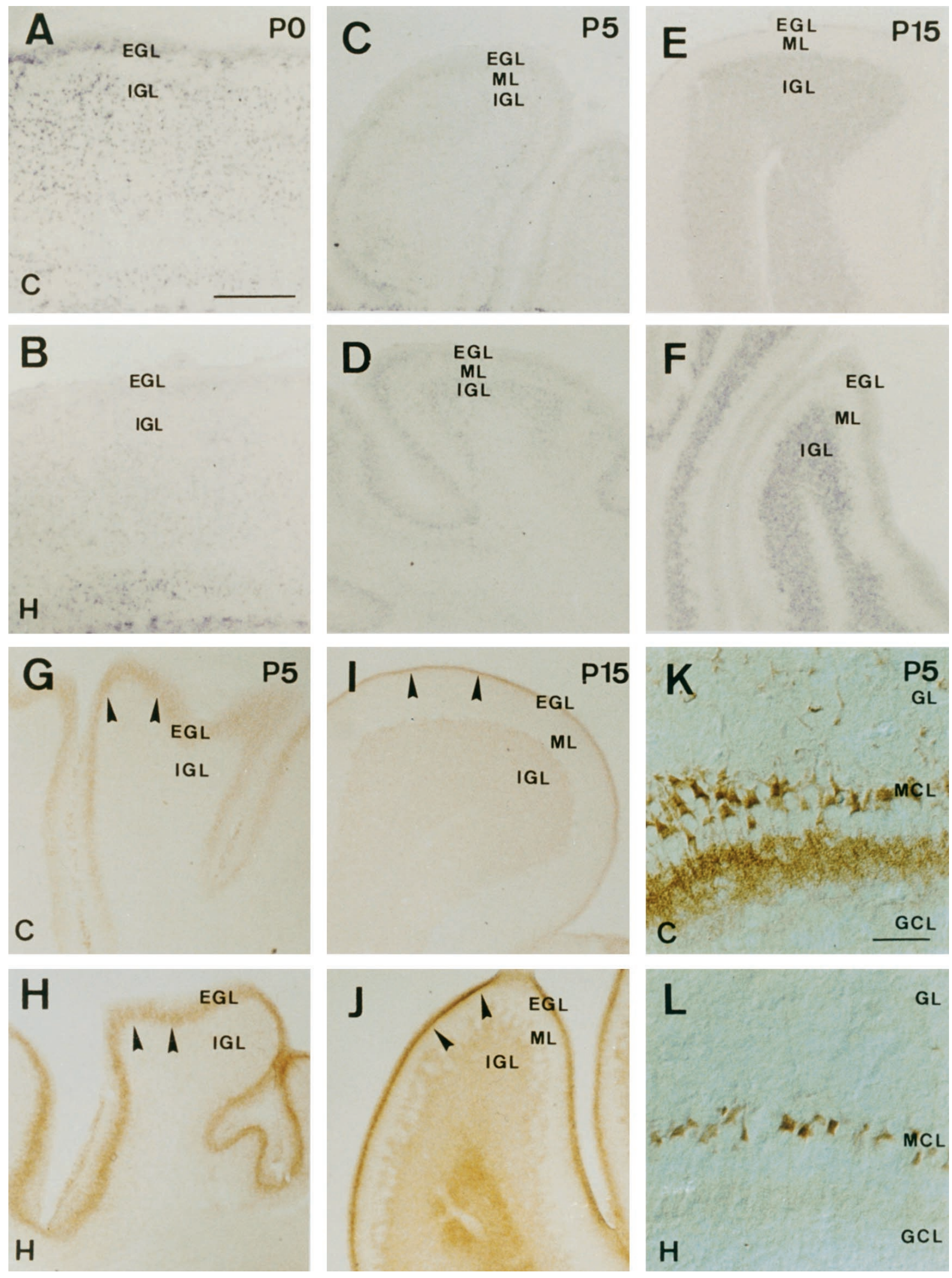

Figure 5. Patterns of reelin RNA and protein distributions in the cerebellum and olfactory bulb of hypothyroid rats. $A$ - $F$, Distribution of reelin RNA in the cerebellum of control $(A, C, E)$ and hypothyroid $(B, D, F)$ rats. Note the decreased RNA levels in hypothyroid rats at P0, and the opposite increased levels at P5 and P15 in these animals. $G-J$, Pattern of CR50 immunostaining in the cerebellum of control $(G, I)$ and hypothyroid $(H, J)$ rats at P5 $(G$, $H)$ and P15 $(I, J)$. Increased Reelin levels are observed in hypothyroid rats. Arrowheads point to the external granule cell layer. $K$, $L$, CR50 immunostaining in the olfactory bulb of control $(K)$ and hypothyroid $(L)$ rats at P5, illustrating the decreased immunolabeling in the mitral cells and glomerular neurons in hypothyroid rats. $E G L$, External granule cell layer; $I G L$, internal granule cell layer; $M L$, molecular layer; $W M$, white matter; $M C L$, mitral cell layer; $G C L$, granule cell layer; $G L$, glomerular cell layer. Scale bars: $A, 200 \mu \mathrm{m}$ (applies to $B-J$ ); $K, 40 \mu \mathrm{m}$ (applies to $L$ ). 


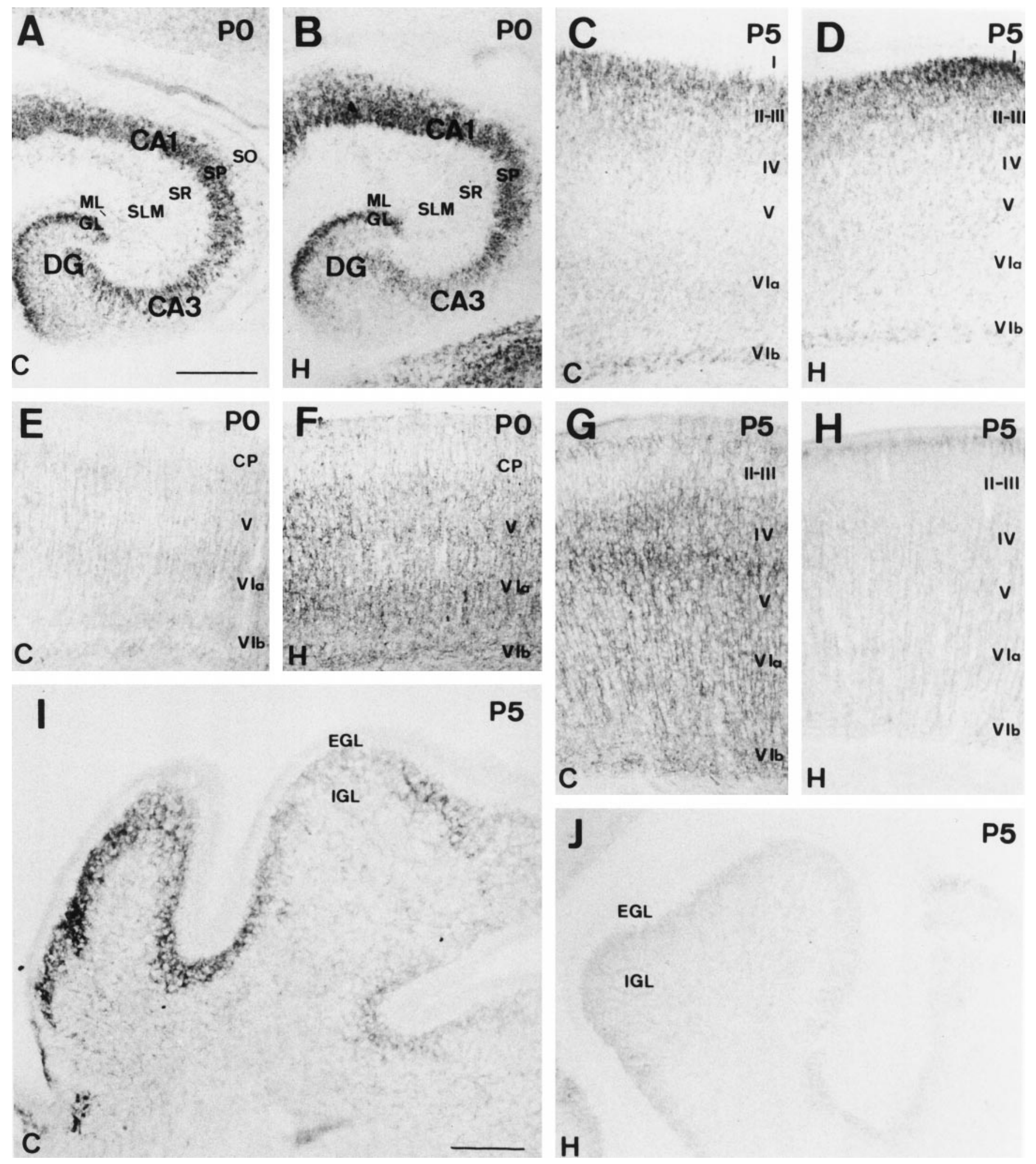

Figure 6. Distribution of dab1 RNA and protein levels in the cerebral cortex and cerebellum of control $(C)$ and hypothyroid $(H)$ rats. $A-D$, Pattern of dab1 RNA hybridization at $\mathrm{P} 0$ and $\mathrm{P} 5$ in control $(A, C)$ and hypothyroid $(B, D)$ rats in the hippocampus $(A, B)$ and neocortex $(C, D)$. dab1 is widely expressed within the cerebral cortex, and no major differences are observed between control and hypothyroid rats. $E-H$, Distribution of Dab1 immunolabeling in the neocortex of control $(E, G)$ and hypothyroid $(F, H)$ rats at P0 and P5. Increased levels of Dab1 immunoreactivity are observed in hypothyroid rats at $\mathrm{P} 0$, whereas the opposite occurs at P5. I, $J$, Photomicrographs illustrating decreased Dab1 immunostaining in the cerebellum of hypothyroid $(J)$ compared to controls $(I)$ rats at P5. Abbreviations are as in legends to Figures 2 and 5. Scale bars: $A, 200 \mu \mathrm{m}($ applies to $B-H) ; I, 100$ $\mu \mathrm{m}$ (applies to $J$ ). 


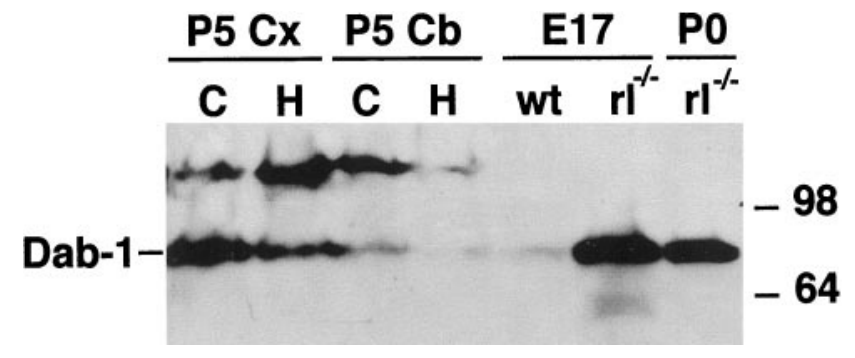

Figure 7. Western blot analysis of the expression of Dab1 in the cortex $(\mathrm{Cx})$ and cerebellum $(\mathrm{Cb})$ of control $(\mathrm{C})$ and hypothyroid $(H)$ rats at P5. Total brain extracts from wild-type (wt) and reeler $\left(\mathrm{rl}^{-/-}\right)$mice at the indicated ages were used as controls, showing a high increase in Dab1 content in reeler mutants. Numbers to the right indicate $\mathrm{Mr}$ of marker proteins.

results, the pattern of reelin mRNA distribution did not differ greatly at P15 between control and hypothyroid rats, but the intensity of labeling was however reduced in the latter animals (Fig. 11A). Hypothyroid rats treated with T4 showed an increase in the number of reelin-positive neurons present in layer I/SLM and in layers V/VI (Fig. 11B). In addition, T4 treatment resulted in a stronger hybridization signal in labeled neurons. Together, these results indicate that reelin RNA and protein expression are regulated by thyroid hormone in vivo.

\section{DISCUSSION}

Reelin and Dab1 are critical for neuronal migration, which in turn is responsible for lamination and precise cellular localization during CNS development. We show here that thyroid hormone, an agent known to exert broad regulatory actions on brain maturation (Legrand, 1984; Dussault and Ruel, 1987; Porterfield and Hendrich, 1993), increases reelin RNA and protein levels. The exact mechanism of T3 action on reelin expression, whether transcriptional or post-transcriptional, remains to be determined. The lack of a strict correlation between the changes in RNA and protein levels might indicate that reelin expression is regulated at multiple levels, perhaps by thyroid hormone. Furthermore, the differences observed in the effect of the hormone in distinct brain regions suggests that $\mathrm{T} 3$ may cooperate with locally acting factors, or that hormone action is modulated by region- or cell-specific proteins. Recently, BDNF has been found to negatively regulate the expression of reelin in CR cells of the cerebral cortex (Ringstedt et al., 1998). At present we do not know if the thyroid hormone effect on reelin is direct or, alternatively, is mediated by the control of BDNF expression. Previous studies indicated that BDNF expression, as measured by RNA protection assays, is diminished at P15 and later ages in the cerebellum of hypothyroid rats (Neveu and Arenas, 1996), although the levels in the cortex and hippocampus remain unchanged (Alvarez-Dolado et al., 1994). Therefore, the increased expression of reelin in the cerebellum at P5-P15 may be secondary to the modulation of BDNF levels in this region.

We show that both the number of Reelin-positive cells and the intensity of signal per cell is reduced in hypothyroid rats. However, we cannot ascertain whether the number of CR cells is affected because there are not known cell markers for the entire population of $\mathrm{CR}$ cells in the rat cortex. Although calretinin appears to label all the CR cell population in mice, antibodies to different calcium-binding proteins, including calretinin and calbindin, only result in the labeling of subpopulations of CR cells (Meyer et al., 1998). Suggesting that hypothyroidism does not affect the number of CR cells, when hippocampal slice cultures from newborn hypothyroid rats (showing a decrease number of Reelin-positive cells) were treated with $\mathrm{T} 3$ in vitro, the number of Reelin-positive CR cells increased dramatically. This indicates that the cells were present at $\mathrm{P} 0$, but had no detectable expression levels. Thus, although we cannot discard the possibility that the lack of thyroid hormone may affect CR cell number or viability, the present data appear to favor that CR cell number is not altered in the hypothyroid state.

It is interesting to note that in contrast to reelin, dab1 RNA levels are not affected by hypothyroidism. However, Dab1 protein levels are modulated in thyroid-deficient rats. This effect may be caused by a direct effect of T3 on dab1 mRNA translation or on Dab1 protein stability. Alternatively, changes in Dab1 protein content may be an indirect consequence of the reduction in reelin expression by the lack of hormone. In fact, reeler mutant mice show normal dab1 mRNA levels but increased Dab1 protein content (Rice et al., 1998).

The possibility that thyroid hormone primarily controls Dab1 levels and as a consequence affects secondarily the expression of reelin RNA and protein cannot be ruled out, but it does not appear very likely since the expression of Reelin is unaltered in scrambler and yotari mice carrying mutations in the dabl gene (Yoneshima et al., 1997; Rice et al., 1998), and dab1 RNA expression is not changed in hypothyroid rats. Given the important role of these proteins in migration, it is conceivable that the profound alteration in Reelin/Dab1 levels may affect this process in the hypothyroid brain.

Thyroid hormone exerts its wide regulatory actions by controlling gene expression. In the last years, a number of genes have been described by us and others to be under thyroid control in the CNS (for review, see Bernal and Guadaño-Ferraz, 1998). The classical mechanism of action of T3 is the regulation of gene transcription through the binding to specific nuclear receptors (TR $\alpha 1, \mathrm{TR} \beta 1$, and $\mathrm{TR} \beta 2$ isoforms) that interact with specific nucleotide sequences (T3REs: thyroid response elements) present in target genes, usually in the form of heterodimers with the RXR 9-cis retinoic acid receptor (Lazar, 1993; Muñoz and Bernal, 1997). T3 can regulate gene transcription through the activation of positive T3REs or repression of negative T3REs, or by interference with other transcription factors (Muñoz and Bernal, 1997). In addition, several studies have indicated posttranscriptional regulatory effects of T3 on mRNA stabilization, processing, and translation, or on post-translational mechanisms (Aniello et al., 1991). Besides the above discussed data on BDNF expression, we and others have previously reported a positive regulation of nerve growth factor (NGF), the trkA gene encoding its high-affinity receptor, and neurotrophin (NT)-3 genes by thyroid hormone during rat brain development (Walker et al., 1982; Lindholm et al., 1993; Alvarez-Dolado et al., 1994). In contrast, abnormally higher levels of the p $75^{\text {LNGFR }}$ low-affinity receptor for neurotrophins are expressed in the hypothyroid brain (Figueiredo et al., 1993; Alvarez-Dolado et al., 1994). These data are in line with the functional interplay described between thyroid hormone and NGF in the developing rodent brain and in vitro in pheochromocytoma PC12 cells (Patel et al., 1988; Clos and Legrand, 1990; Muñoz et al., 1993).

Cell migration is known to be altered by hypothyroidism in the neonatal cerebellum (for review, see Legrand, 1984). The migration of cerebellar granule cells from the external to the internal layer is delayed as a consequence of a reduction in their rate of 


\section{CONTROL}
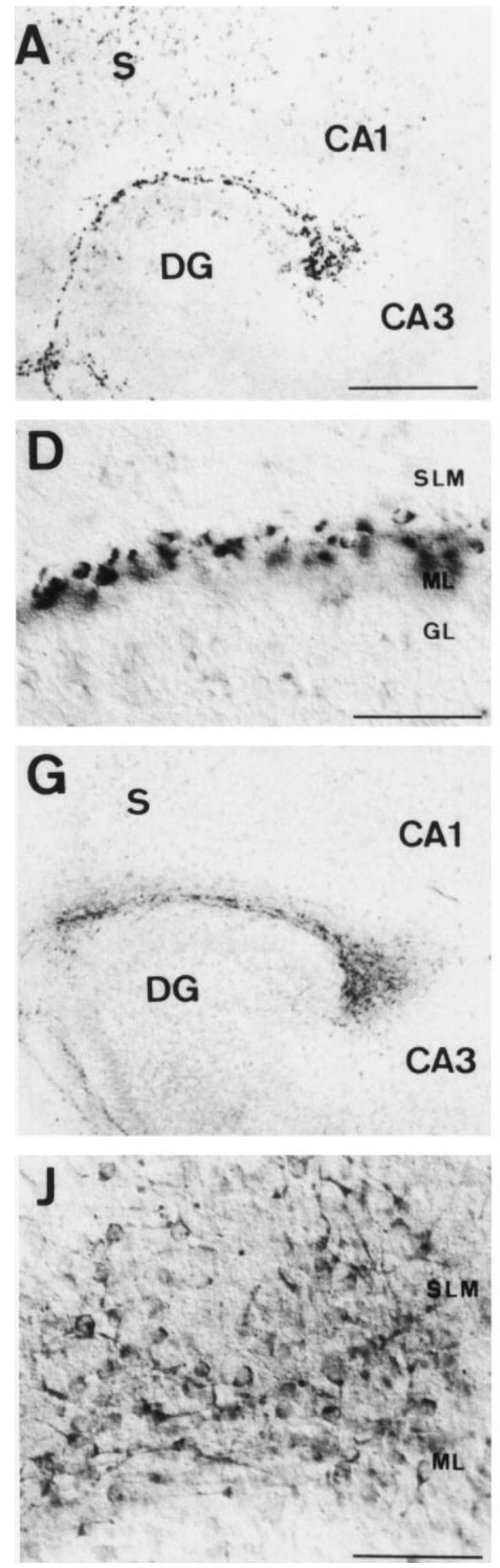

HYPO

B $s$
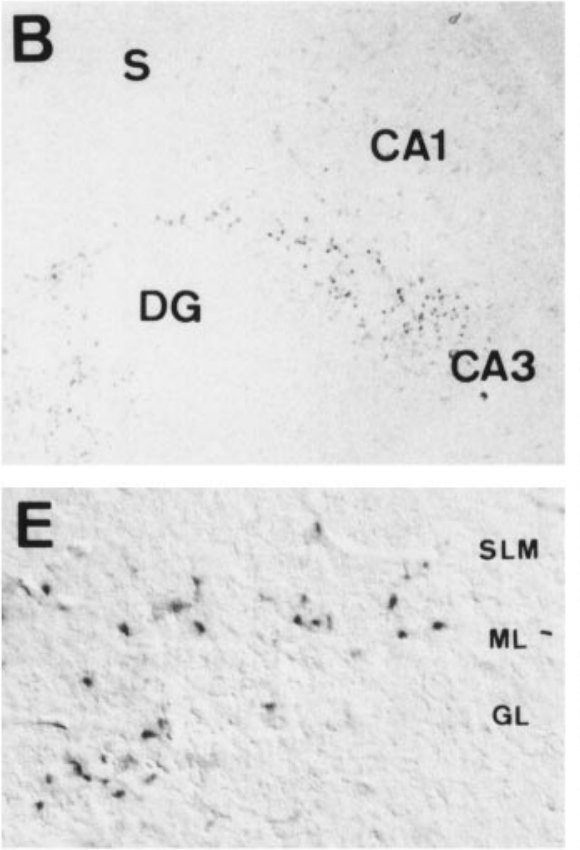

$\mathrm{H}$ s

\section{HYPO+ ${ }_{3}$}
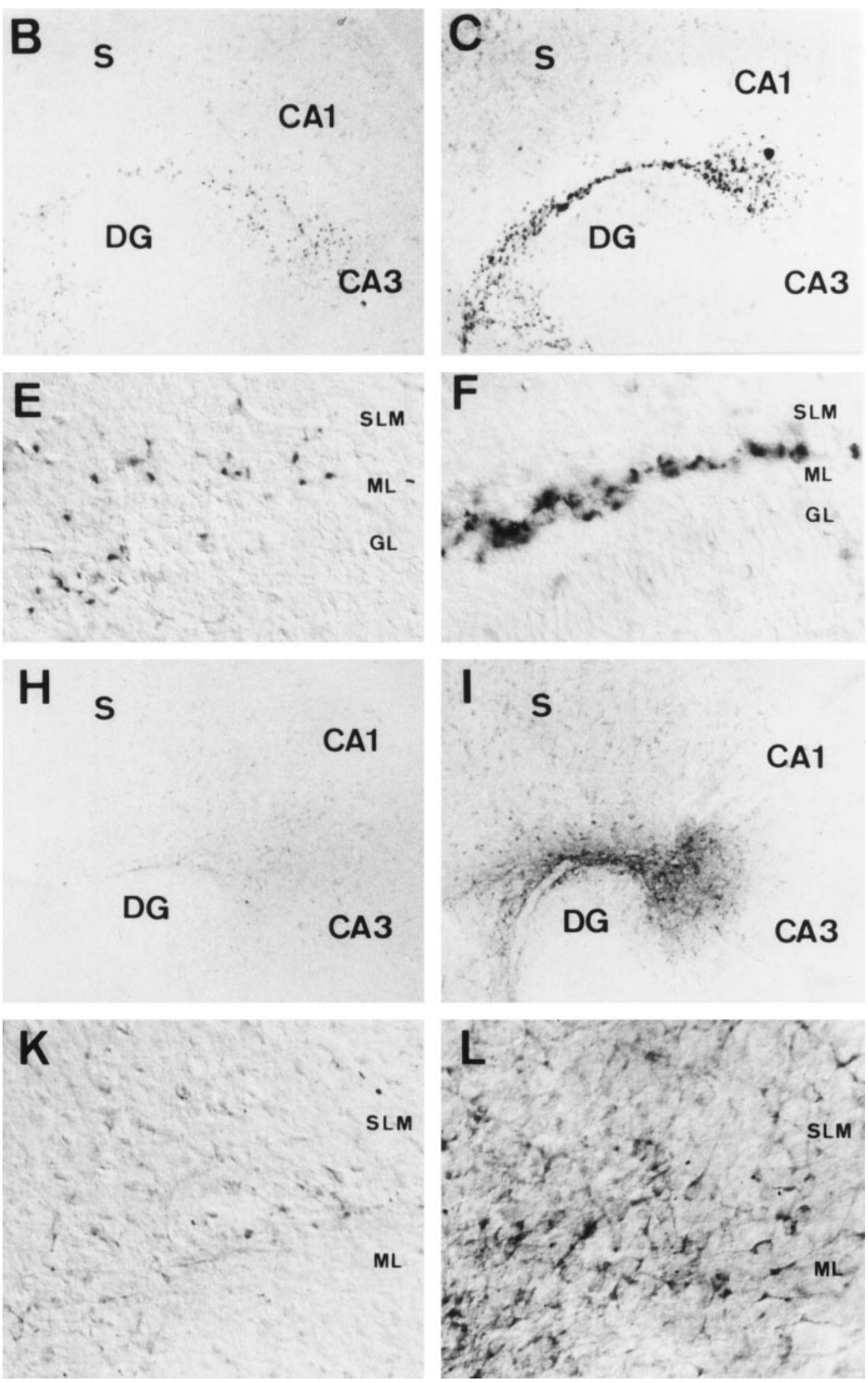

CA1

CA3

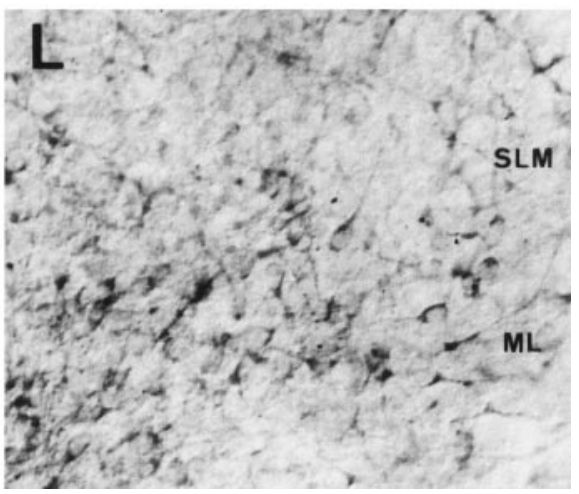

Figure 8. reelin RNA $(A-F)$ and protein $(G-L)$ expression in hippocampal organotypic slice cultures. Left panels, $(A-J)$, Slices from euthyroid rats incubated for $6 \mathrm{~d}$ in standard serum. Middle panels, $(B-K)$, Slices from hypothyroid rats incubated for $6 \mathrm{~d}$ in thyroid-depleted serum. Right panels, $(C-L)$, Slices from hypothyroid rats incubated for $6 \mathrm{~d}$ in T3/T4-depleted serum supplemented with $500 \mathrm{~nm}$ T3. Note that the reduced expression levels in hypothyroid slices are rescued by T3 treatment. Higher magnification photomicrographs illustrating reelin RNA $(D-F)$ and protein $(J-L)$ in the CR cells of the hippocampus are shown. Abbreviations are as in legends to Figure $2 ; S$, subiculum. Scale bars: $A, 300 \mu \mathrm{m}$ (applies to $B, C$, and $G-I$ ); $D$, $75 \mu \mathrm{m}$ (applies to $E, F) ; J, 50 \mu \mathrm{m}$ (applies to $K, L$ ).

movement through the molecular layer and Bergmann glia (Lauder, 1979). In addition, ectopic localization of Purkinje cells is a typical abnormality found in the hypothyroid cerebellum, which remarkably also occurs to much higher extent in reeler mice
(Mariani et al., 1977; Legrand, 1984; Miyata et al., 1997 and references therein). In contrast, cerebral neuronal migration has been traditionally considered to be unaltered by hypothyroidism, possibly because of the fact that this process is mostly completed 
Figure 9. Density of reelin RNApositive neurons in the stratum lacunosum-moleculare of hippocampal slice cultures from control and hypothyroid newborn (P0) rats. Organotypic slices were incubated in standard normal serum $(N S)$ or in T3/T4-depleted serum $(D S)$ supplemented or not with $\mathrm{T} 3$ as indicated. For statistical analysis, T3-treated slices were compared to untreated DS slices. Note the increase in reelin-positive cells caused by $\mathrm{T} 3$ treatment. Data were quantitated as described in Materials and Methods (mean $\pm \mathrm{SEM} ;{ }^{*} p<0.05$ ). Each value corresponds to five strips of two different slices.
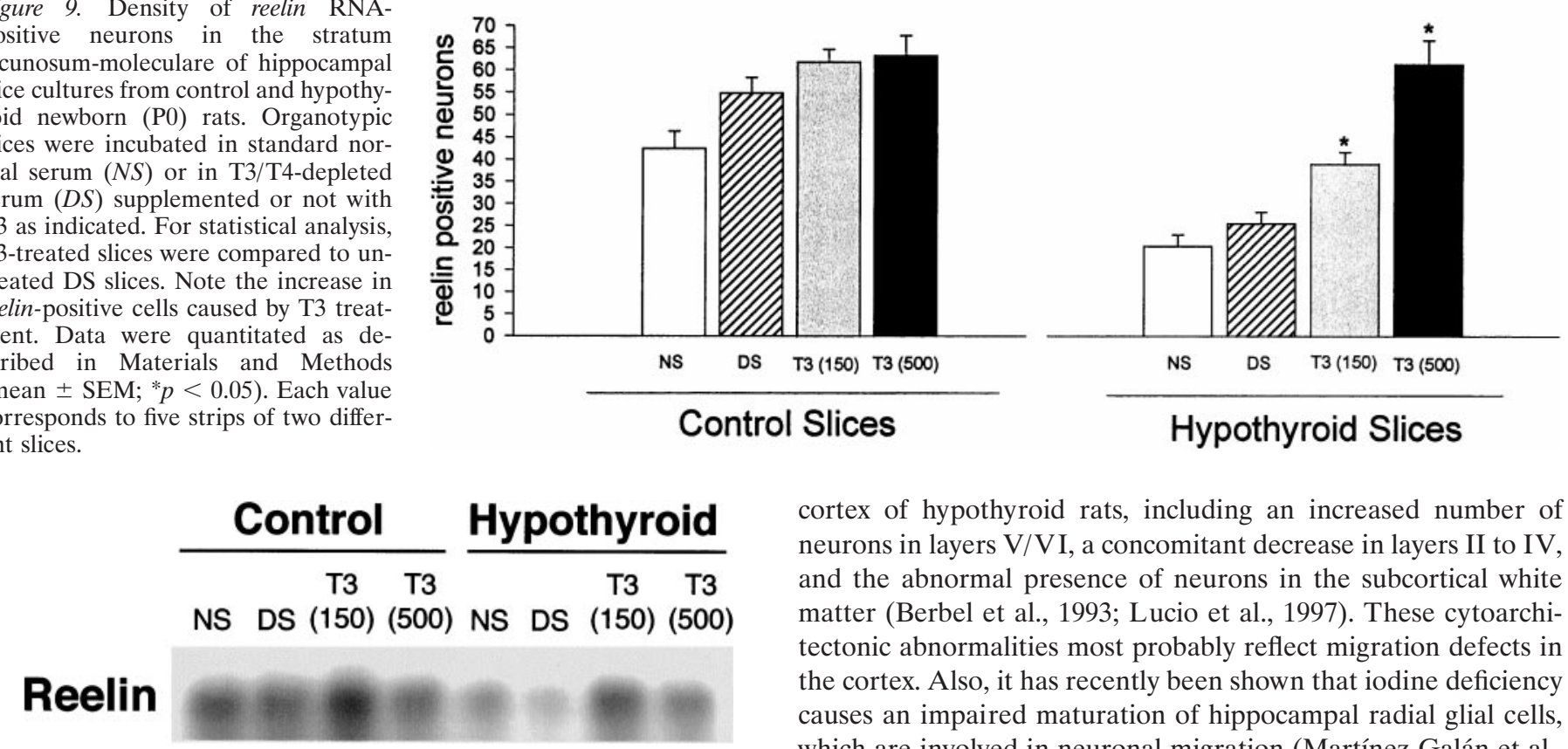

\section{GAPDH}

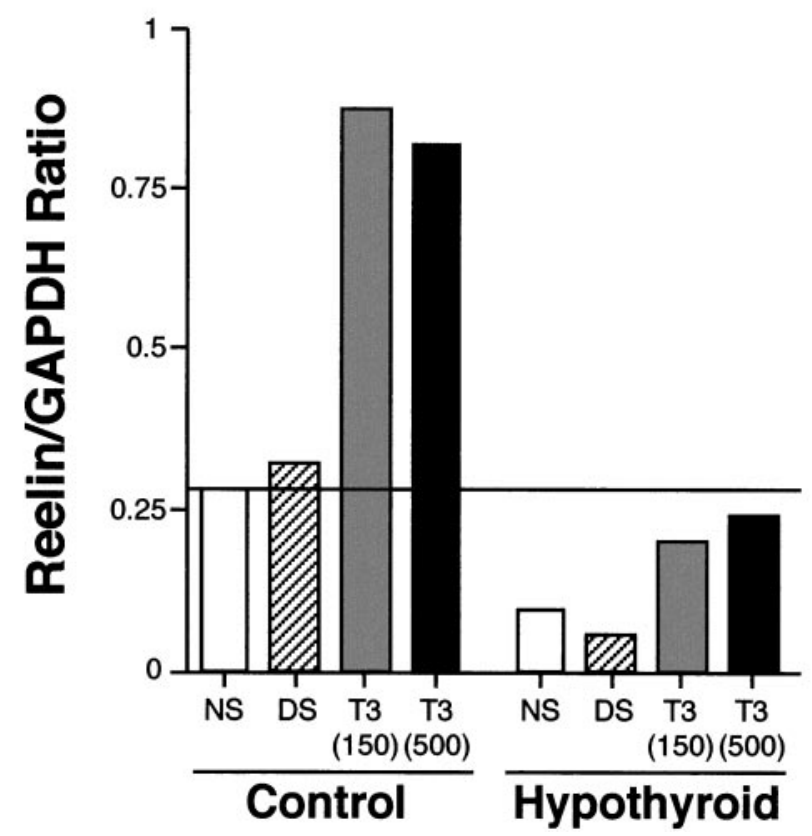

Figure 10. RT-PCR analysis of reelin RNA expression in organotypic cultures. $A$, Total RNAs were prepared from the same four types of slices as in legend to Figure 9 and then were retrotranscribed and analyzed as described in Materials and Methods to estimate the expression of reelin RNA. GAPDH gene was used as internal control. $B$, Quantitation of the reelin/GAPDH ratio of RNA expression.

before birth, and also by the presumption that the fetal brain is insensitive to thyroid hormone (Schwartz et al., 1997). However, recent data have led to a reconsideration of this notion. An abnormal laminar distribution has been reported in the auditory cortex of hypothyroid rats, including an increased number of neurons in layers V/VI, a concomitant decrease in layers II to IV, and the abnormal presence of neurons in the subcortical white matter (Berbel et al., 1993; Lucio et al., 1997). These cytoarchitectonic abnormalities most probably reflect migration defects in the cortex. Also, it has recently been shown that iodine deficiency causes an impaired maturation of hippocampal radial glial cells, which are involved in neuronal migration (Martínez-Galán et al., 1997). Additionally, hypothyroidism affects the migration of cells from germinative zones toward the olfactory bulb and caudate putamen region (Patel et al., 1976; Lu and Brown, 1977). These observations can be linked to the reduction in Reelin content in the hypothyroid brain during the perinatal period reported here. The abnormal expression of reelin at around birth argues against the proposed thyroid resistance of the fetal brain and clearly indicates that reelin is an early target of thyroid action during late fetal development.

This work provides the first demonstration that thyroid hormone regulates the expression of reelin, a gene implicated in the control of neuronal migration. Recently, other mutant mice such as those lacking the $c d k 5$ or $p 35$ genes have been shown to display also migration deficits that disrupt normal cortical lamination (Ohshima et al., 1996; Chae et al., 1997; Kwon and Tsai, 1998). Although the patterns of alterations throughout the brains of these mice are distinct, suggesting that $p 35 / c d k 5$ and reelin probably signal through different pathways, our results suggest that it may be interesting to analyze whether $c d k 5 / p 35$ are under thyroid control.

Our results show that the migration deficits observed in the hypothyroid brain may in part be caused by alterations in reelin expression. Previously, we reported changes in the expression of other genes such as tenascin-C and neural cell adhesion molecule, which could also contribute to alterations in cell migration (Iglesias et al., 1996; Alvarez-Dolado et al., 1998). The complexity of the processes underlying cell migration (dynamic changes in cytoskeleton and in cell to cell and cell to matrix adhesion, active movement, degradation of extracellular matrix) suggests the existence of multiple sites of possible regulation. Among them, and according to the drastic phenotype caused by its lack of expression, reelin seems to be clearly relevant. The finding that thyroid hormone influences reelin expression suggests a molecular mechanism that may be of fundamental importance in understanding the alterations that occur in the hypothyroid brain during development. 

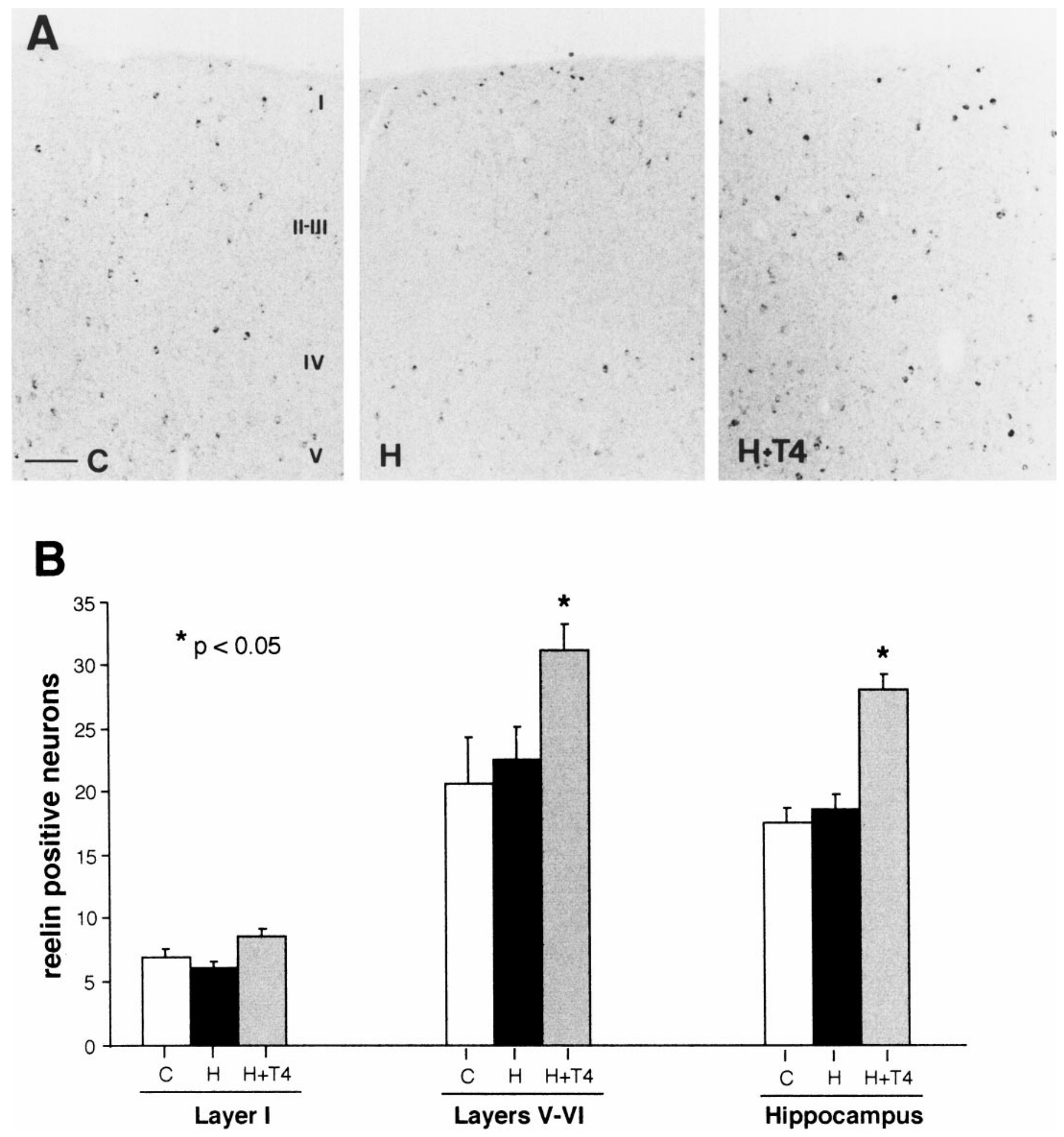

Figure 11. Effect of thyroid hormone treatment in vivo on the number of reelin-positive cells present in $\mathrm{P} 15$ rats. $A$, Photomicrographs illustrating the level of reelin RNA expression in the parietal cortex of control $(C)$, hypothyroid $(H)$, and hypothyroid rats treated with T4 $(H+T 4)$, as described in Materials and Methods. B, Number of reelin RNA-positive neurons in the neocortex (layers I and V/VI) and hippocampus (SLM) of the three groups of animals. Data were quantitated as described in Materials and Methods (mean \pm SEM; ${ }^{*} p<0.05$ ). For cortical layer I and SLM each value corresponds to three strips of four different animals, and for layers V/VI to four sections of three animals. Abbreviations are as in legend to Figure 2 . Scale bar, $100 \mu \mathrm{m}$.

\section{REFERENCES}

Alcántara S, Ruiz M, D’Arcangelo G, Ezan F, de Lecea L, Curran T, Sotelo C, Soriano E (1998) Regional and cellular patterns of reelin mRNA expression in the forebrain of the developing and adult mouse. J Neurosci 18:7779-7799.
Alvarez-Dolado M, Iglesias T, Rodríguez-Peña A, Bernal J, Muñoz A (1994) Expression of neurotrophins and the trk family of neurotrophin receptors in normal and hypothyroid rat brain. Mol Brain Res 27:249-257.

Alvarez-Dolado M, González-Sancho J, Bernal J, Muñoz A (1998) De- 
velopmental expression of tenascin-C is altered by hypothyroidism in the rat brain. Neuroscience 84:309-322.

Aniello F, Couchie D, Bridoux AM, Gripois D, Nunez J (1991) Splicing of juvenile and adult tau m-RNA variants is regulated by thyroid hormone. Proc Natl Acad Sci USA 88:4035-4039.

Berbel P, Guadaño-Ferraz A, Martínez M, Quiles J, Balboa R, and Innocenti G (1993) Organization of auditory callosal connections in hypothyroid rats. Eur J Neurosci 5:1465-1478.

Bernal J, Guadaño-Ferraz A (1998) Thyroid hormone and the development of the brain. Curr Opin Endocrinol Diabetes 5:296-302.

Borrell V, Del Río JA, Alcántara S, Derer M, D’Arcangelo G, Nakajima K, Mikoshiba K, Derer P, Curran T, Soriano E (1999) Reelin regulates the development and synaptogenesis of layer-specific hippocampal connections. J Neurosci 19:1345-1358.

Caviness Jr VS, Sidman RL (1973) Time of origin of corresponding cell classes in the cerebral cortex of normal and mutant reeler mice: an autoradiographic analysis. J Comp Neurol 148:141-152.

Chae T, Kwon YT, Bronson R, Dikkes P, Li E, Tsai LH (1997) Mice lacking p35, a neuronal specific activator of $\mathrm{Cdk} 5$, display cortical lamination defects, seizures, and adult lethality. Neuron 18:29-42.

Chomczynski P, Sacchi N (1987) Single step method of RNA isolation by acid guanidinium thiocyanate-phenol-chloroform extraction. Anal Biochem 162:156-159.

Clos J, Legrand CH (1990) An interaction between thyroid hormone and nerve growth factor promotes the development of hippocampus, olfactory bulbs and cerebellum: a comparative biochemical study of normal and hypothyroid rats. Growth Factor 3:205-220.

D'Arcangelo G, Miao GG, Chen S-C, Soares HD, Morgan JI, Curran T (1995) A protein related to extracellular matrix proteins deleted in the mouse mutant reeler. Nature 374:719-723.

D’Arcangelo G, Nakajima K, Miyata T, Ogawa M, Mikoshiba K, Curran T (1997) Reelin is a secreted glycoprotein recognized by the CR-50 monoclonal antibody. J Neurosci 17:23-31.

de Lecea L, Soriano E, Criado JR, Steffensen SL, Henriksen SJ, Sutcliffe JG (1994) Transcripts encoding a neural membrane CD26 peptidaselike protein are stimulated by synaptic activity. Mol Brain Res 25:286-296.

de Lecea L, Del Río JA, Criado JR, Alcántara S, Morales M, Henriksen SJ, Soriano E, Sutcliffe JG (1997) Cortistatin is expressed in a distinct subset of cortical interneurons. J Neurosci 17:5868-5880.

DeLong GR (1990) The effect of iodine deficiency on neuromuscular development. IDD Newsletter 6:1-12.

Del Río JA, Martínez A, Fonseca M, Auladell C, Soriano E (1995) Glutamate-like immunoreactivity and fate of Cajal-Retzius cells in the murine cortex as identified with calretinin antibody. Cereb Cortex $5: 13-21$.

Del Río JA, Heimrich B, Supèr H, Borrell V, Frotscher M, Soriano E (1996) Differential survival of Cajal-Retzius cells in organotypic slice cultures of neocortex and hippocampus. J Neurosci 16:6896-6907.

Del Río JA, Heimrich B, Borrell V, Forster, E, Drakew A, Alcántara S, Nakajima K, Miyata T, Ogawa M, Mikoshiba M, Derer P, Frotscher M, Soriano E (1997) A role for Cajal-Retzius cells and Reelin in the development of hippocampal connections. Nature 385:70-75.

Derer P (1985) Comparative localization of Cajal-Retzius cells in the neocortex of normal and reeler mutant mice fetuses. Neurosci Lett 54:1-6.

des Portes V, Pinard JM, Billuart P, Vinet MC, Koulakoff A, Carrié A, Gelot A, Dupuis E, Motte J, Berwald-Netter Y, Catala M, Kahn A, Beldjord C, Chelly J (1998) A novel CNS gene required for neuronal migration and involved in X-linked subcortical laminar heterotopia and lissencephaly syndrome. Cell 92:51-61.

Dickson PW, Aldred AR, Menting JGT, Marley PD, Sawyer WH, Schreiber G (1987) Thyroxine transport in choroid plexus. J Biol Chem 262:13907-13915.

Dussault JH, Ruel J (1987) Thyroid hormones and brain development. Annu Rev Physiol 49:321-334.

Eksloglu YZ, Scheffer IE, Cardenas P, Knoll J, DiMario F, Ramsby G, Berg M, Kamuro K, Berkovic SF, Duyk GM, Parisi J, Huttenlocker PR, Walsh CA (1996) Periventricular heterotopia: An X-linked dominant epilepsy locus causing aberrant cerebral cortical development. Neuron 16:77-87.

Feinberg PA, Vogelstein B (1983) A technique for radiolabeling DNA restriction endonuclease fragments to high specific activity. Anal Biochem 137:266-267.

Figueiredo BC, Almazán G, Ma Y, Teztlaff W, Miller FD, Cuello AC
(1993) Gene expression in the developing cerebellum during perinatal hypo- and hyperthyroidism. Mol Brain Res 17:258-268.

Gleeson JG, Allen KM, Fox JW, Lamperti ED, Berkovic S, Scheffer I, Cooper EC, Dobyns WB, Minnrath SR, Ross ME, Walsh CA (1998) doublecortin, a brain-specific gene mutated in human X-linked lissencephaly and double cortex syndrome, encodes a putative signaling protein. Cell 92:63-72.

Goffinet AM (1980) The cerebral cortex of the reeler embryo (an electron microscopic analysis). Anat Embryol 159:199-210.

Goffinet AM (1992) The reeler gene: a clue to brain development and evolution. Int J Dev Biol 36:101-107.

Hatten ME (1993) The role of migration in central nervous system neuronal development. Curr Opin Neurobiol 3:38-44.

Hirotsune S, Takahara T, Sasaki N, Hirose K, Yoshiki A, Ohashi T, Kusakabe M, Murakami Y, Muramatsu M, Watanabe S, Nakao K, Katsuki M, Hayashizaki Y (1995) The reeler gene encodes a protein with an EGF-like motif expressed by pioneer neurons. Nat Genet 10:77-83.

Howell BW, Gertler FB, Cooper JA (1997a) Mouse disabled (mdab1): a Src-binding protein implicated in neuronal development. EMBO J 16:121-132.

Howell BW, Hawkes R, Soriano P, Cooper JA (1997b) Neuronal position in the developing brain is regulated by mouse disabled-1. Nature 389:733-737.

Howell BW, Herrick TM, Cooper JA (1999) Reelin-induced tyrosine phosphorylation of disabled 1 during neuronal positioning. Genes Dev 13:643-648.

Iglesias T, Caubín J, Stunnenberg HG, Zaballos A, Bernal J, Muñoz A (1996) Thyroid hormone-dependent transcriptional repression of neuronal cell adhesion molecule during brain maturation. EMBO J 15:4307-4316.

Kwon YT, Tsai LH (1998) A novel disruption of cortical development in p35 ${ }^{-1-}$ mice distinct from reeler. J Comp Neurol 395:510-522.

Lauder JM (1979) Granule cell migration in the developing rat cerebellum. Influence of neonatal hypo- and hyper-thyroidism. Dev Biol 70:105.

Lazar MA (1993) Thyroid hormone receptors: multiple forms, multiple possibilities. Endocr Rev 14:184-193.

Legrand J (1984) Effects of thyroid hormones on central nervous system. In: Neurobehavioural teratology (Yanai J, ed), pp 331-363. Amsterdam: Elsevier/North Holland.

Lindholm D, Castrén E, Tsoulfas P, Kolbel R, Berzaghi MP, Leingärtner A, Heisenberg CP, Tesarollo L, Parada LP, Thoenen H (1993) Neurotrophin-3 induced by triiodothyronine in cerebellar granule cells promotes Purkinje cell differentiation. J Cell Biol 122:443-450.

Lu E, Brown W (1977) The developing caudate nucleus in the euthyroid and hypothyroid rat. J Comp Neurol 171:261-284.

Lucio RA, García JV, Cerezo JR, Pacheco P, Innocenti GM, Berbel P (1997) The development of auditory callosal connections in normal and hypothyroid rats. Cereb Cortex 7:303-316.

Marchant B, Brownlie BEW, Hart DM, Horton PW, Alexander WD (1977) The placental transfer of propylthiouracil, methimazole and carbamidazole. J Clin Endocrinol Metab 45:1187-1193.

Mariani J, Crepel F, Mikoshiba K, Changeux JP, Sotelo C (1977) Anatomical, physiological and biochemical studies of the cerebellum from reeler mutant mouse. Philos Trans R Soc Lond B Biol Sci 281:1-28.

Marín-Padilla M (1971) Early prenatal ontogenesis of the cerebral cortex (neocortex) of the Felix domestica. A Golgi study. I. The primordial neocortical organization. Z Anat Entwicklungsgesch 134:117-145.

Marín-Padilla M (1998) Cajal-Retzius cells and the development of the neocortex. Trends Neurosci 21:64-71.

Martínez-Galán J, Pedraza P, Santacana M, Escobar del Rey F, Morreale de Escobar G, Ruiz-Marcos A (1997) Early effects of iodine deficiency on radial glial cells of the hippocampus of the rat fetus. A model of neurological cretinism. J Clin Invest 99:2701-2709.

Meyer G, Soria JM, Martínez-Galán JR, Martín-Clemente B, Fairén A (1998) Different origins and developmental histories of transient neurons in the marginal zone of the fetal and neonatal rat cortex. J Comp Neurol 397:493-518.

Miyata T, Nakajima K, Aruga J, Takahashi S, Ikenaka K, Mikoshiba K, Ogawa M (1996) Distribution of reelin-gene related antigen in the developing cerebellum: an immunohistochemical study with an allogenic antibody CR-50 on normal and reeler mice. J Comp Neurol 372:899-912.

Miyata T, Nakajima K, Aruga J, Mikoshiba K, Ogawa M (1997) Regu- 
lation of Purkinje cell alignment by reelin as reveled with CR-50 antibody. J Neurosci 15:3599-3609.

Muñoz A, Bernal J (1997) Biological activities of thyroid hormone receptors. Eur J Endocrinol 137:433-445.

Muñoz A, Rodríguez-Peña A, Pérez-Castillo A, Ferreiro B, Sutcliffe JG, Bernal J (1991) Effects of neonatal hypothyroidism on rat brain gene expression. Mol Endocrinol 5:273-280.

Muñoz A, Wrighton C, Seliger B, Bernal J, Beug H (1993) Thyroid hormone receptor/c-erbA: control of commitment and differentiation in the neuronal/chromaffin progenitor line PC12. J Cell Biol 121:423-438.

Nakajima N, Mikoshiba K, Miyata T, Kudo C, Ogawa M (1997) Disruption of hippocampal development in vivo by CR-50 mAb against Reelin. Proc Natl Acad Sci USA 94:8196-8201.

Neveu I, Arenas E (1996) Neurotrophins promote the survival and development of neurons in the cerebellum of hypothyroid rats in vivo. J Cell Biol 133:631-646.

Ogawa M, Miyata T, Nakajima K, Yagyu K, Seike M, Ikenaka K, Yamamoto H, Mikoshiba K (1995) The reeler gene-associated antigen on Cajal-Retzius neurons is a crucial molecule for laminar organization of cortical neurons. Neuron 14:899-912.

Ohshima T, Ward JM, Huh CG, Longenecker G, Veeranna, Pant HC, Brady RO, Martin LJ, Kulkarni AB (1996) Targeted disruption of the cyclin-dependent kinase 5 gene results in abnormal corticogenesis, neuronal pathology and perinatal death. Proc Natl Acad Sci USA 93:11173-11178.

Oppenheimer JH, Schwartz HL (1997) Molecular basis of thyroid hormone-dependent brain development. Endocr Rev 18:462-475.

Patel AJ, Rabie A, Lewis P, Balazs R (1976) Effects of thyroid deficiency on postnatal cell formation in the rat brain. A biochemical investigation. Brain Res 104:33-48.

Patel AJ, Hayashi M, Hunt A (1988) Role of thyroid hormone and nerve growth factor in the development of choline acetyltransferase and other cell-specific marker enzymes in the basal forebrain of the rat. J Neurochem 50:803-811.

Paxinos G, Törk I, Tecott LH, Valentino KL (1994) Atlas of the developing rat brain. London: Academic.

Porterfield SP, Hendrich CE (1993) The role of thyroid hormones in prenatal and neonatal neurological development. Current perspectives. Endocr Rev 14:94-106.

Rakic P (1988) Specification of cerebral cortical areas. Science 241:170-176.

Rakic P (1990) Principles of neural cell migration. Experientia 46:882-891.

Rakic P, Caviness Jr VS (1995) Cortical development: view from neurological mutants two decades later. Neuron 14:1101-1103.

Rice DS, Sheldon M, D'Arcangelo G, Nakajima K, Goldowitz D, Curran T (1998) Disabled-1 acts downstream of Reelin in a signaling pathway that controls laminar organization in the mammalian brain. Development 125:3719-3729.

Ringstedt T, Linnarsson S, Wagner J, Lendahl U, Kokaia Z, Arenas E,
Ernfors P, Ibañez CF (1998) BDNF regulates reelin expression and cajal-retzius cell development in the cerebral cortex. Neuron 21:305-315.

Rodríguez-Peña A Ibarrola N, Iñiguez MA, Muñoz A, Bernal J (1993) Neonatal hypothyroidism affects the timely expression of myelinassociated glycoprotein in the rat brain. J Clin Invest 91:812-818.

Sabath DE, Broome HE, Prytowsky MB (1990) Glyceraldehyde-3phosphate dehydrogenase mRNA is a major interleukin 2-induced transcript in a cloned T-helper lymphocyte. Gene 91:185-191.

Sambrook J, Fritsch EF, Maniatis T (1989) Molecular Cloning: a Laboratory Manual, Ed 2, Cold Spring Harbor, NY: Cold Spring Harbour Laboratory.

Schiffmann SN, Bernier B, Goffinet A (1997) reelin mRNA expression during mouse brain development. Eur J Neurosci 9:1055-1071.

Schwartz HL, Ross M, Oppenheimer JH (1997) Lack of effects of thyroid hormone on late fetal rat brain development. Endocrinology 138:3119-3124.

Sheldon M, Rice DS, D’Arcangelo G, Yoneshima H, Nakajima K, Mikoshiba K, Howell BW, Cooper JA, Goldowitz D, Curran T (1997) scrambler and yotari disrupt the disabled gene and produce a reeler-like phenotype in mice. Nature 389:730-733.

Sidman RL, Angevine Jr JB, Taber-Pierce E (1971) Atlas of the mouse brain and spinal cord. Cambridge, MA: Harvard UP.

Soriano E, Del Río J A, Martínez A, and Supèr H (1994) Organization of the embryonic and early postnatal murine hippocampus. I. Immunocytochemical characterization of neuronal populations in the subplate and marginal zone. J Comp Neurol 342:571-595.

Stoppini L, Buchs PA, Muller D (1991) A simple method for organotypic cultures of nervous tissue. J Neurosci Methods 37:173-182.

Vennström B, Bishop JM (1982) Isolation and characterization of chicken DNA homologous to the two putative oncogenes of avian erythroblastosis virus. Cell 28:135-143.

Walker P, Weichsel ME, Eveleth D, Fisher DA (1982) Ontogenesis of nerve growth factor and epidermal growth factor in submaxillary glands and nerve growth factor in brains of immature male mice: correlation with ontogenesis of serum levels of thyroid hormones. Pediatr Res 16:520-524.

Xanthoudakis S, Miao G, Wang F, Pan YC, Curran T (1992) Redox activation of Fos-Jun DNA binding activity is mediated by a DNA repair enzyme. EMBO J 11:3323-3335.

Yamada T, Kajihara A, Takemura Y, Onaya T (1974) Antithyroid compounds. In: Handbook of Physiology (Greer MA, Solomon DH, eds), section 7, Vol 3, pp. 345-357. Washington: American Physiology Society.

Yoneshima H, Nagata E, Matsumoto M, Yamada M, Makajima K, Miyata T, Ogawa M, Mikoshiba K (1997) A novel neurological mutant mouse, yotari, which exhibits reeler- like phenotype but expresses CR-50 antigen/reelin. Neurosci Res 29:217-223.

Zilles K (1985) The cortex of the rat. A stereotaxic atlas. Berlin: Springer. 